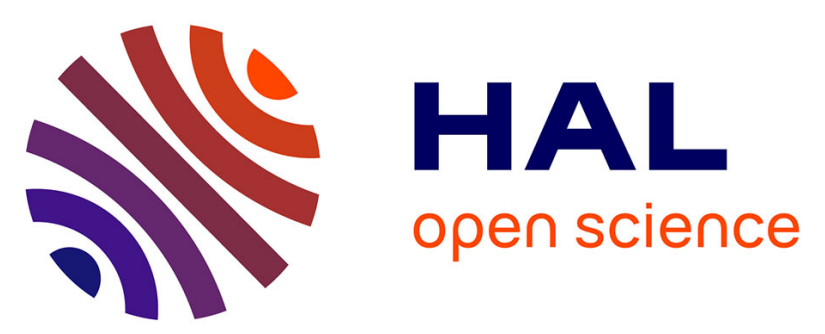

\title{
Metal immobilization and soil amendment efficiency at a contaminated sediment landfill site: a field study focusing on plants, springtails, and bacteria
}

Valérie Bert, Christine Lors, Jean-François Ponge, Lucie Caron, Asmaa Biaz, Marc Dazy, Jean-François Masfaraud

\section{To cite this version:}

Valérie Bert, Christine Lors, Jean-François Ponge, Lucie Caron, Asmaa Biaz, et al.. Metal immobilization and soil amendment efficiency at a contaminated sediment landfill site: a field study focusing on plants, springtails, and bacteria. Environmental Pollution, 2012, 169, pp.1-11. 10.1016/j.envpol.2012.04.021 . hal-00704382

\section{HAL Id: hal-00704382 \\ https://hal.science/hal-00704382}

Submitted on 5 Jun 2012

HAL is a multi-disciplinary open access archive for the deposit and dissemination of scientific research documents, whether they are published or not. The documents may come from teaching and research institutions in France or abroad, or from public or private research centers.
L'archive ouverte pluridisciplinaire HAL, est destinée au dépôt et à la diffusion de documents scientifiques de niveau recherche, publiés ou non, émanant des établissements d'enseignement et de recherche français ou étrangers, des laboratoires publics ou privés. 
1 Environmental Pollution

$2 \quad$ Full Research Paper

3 Title: Metal immobilization and soil amendment efficiency at a contaminated sediment

$4 \quad$ landfill site: a field study focusing on plants, springtails, and bacteria

\section{Author names and affiliations:}

6 Valerie Bert ${ }^{\mathrm{a}, \mathrm{b},{ }^{*}}$, Christine Lors ${ }^{\mathrm{b}, \mathrm{c}, \mathrm{d}}$, Jean-François Ponge ${ }^{\mathrm{e}}$, Lucie Caron ${ }^{\mathrm{a}}$, Asmaa Biaz

$7 \quad$ e, Marc Dazy ${ }^{\mathrm{f}}$, Jean-François Masfaraud ${ }^{\mathrm{f}}$

$8 \quad{ }^{a}$ INERIS, RISK, DRC, Technologies et Procédés Propres et Durables, Parc

9 Technologique Alata, BP2, F-60550 Verneuil en Halatte, France

$10{ }^{\mathrm{b}}$ Centre National de Recherche sur les Sites et Sols Pollués, BP 537, 59505 Douai

11 Cedex, France

$12{ }^{\mathrm{c}}$ Université Lille Nord de France, 1 bis rue Georges Lefèvre, 59044 Lille Cedex, France

$13{ }^{d}$ Ecole des Mines de Douai, LGCgE-GCE, 941, rue Charles Bourseul, 59500 Douai 14 Cedex, France

15

${ }^{\text {e }}$ Muséum National d'Histoire Naturelle, CNRS UMR 7179, 4 avenue du Petit-Château,

$18{ }^{\mathrm{f}}$ Université Paul Verlaine-Metz, Laboratoire "Interactions Ecotoxicologie, Biodiversité, 19 Ecosystèmes", CNRS UMR 7146, Campus Bridoux, rue du général Delestraint, 57070 20 Metz, France

*Corresponding author. Tel.: +33 3445563 82; fax: +33 344556556 .

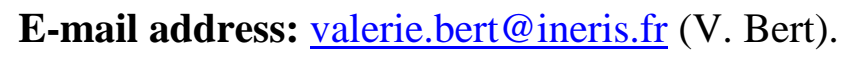




\section{Capsule}

In-situ incorporation of Thomas Basic Slag into a landfilled metal-contaminated sediment decreases metal mobility and ecotoxicity and increases bacterial activity.

\section{Abstract}

Metal immobilization may contribute to the environmental management strategy of dredged sediment landfill sites contaminated by metals. In a field experiment, amendment effects and efficiency were investigated, focusing on plants, springtails and bacteria colonisation, metal extractability and sediment ecotoxicity. Conversely to hydroxylapatite (HA, $3 \%$ DW), the addition of Thomas Basic Slag (TBS, $5 \%$ DW) to a 5-yr deposited sediment contaminated with $\mathrm{Zn}, \mathrm{Cd}, \mathrm{Cu}, \mathrm{Pb}$ and $\mathrm{As}$ resulted in a decrease in the $0.01 \mathrm{M} \mathrm{Ca}\left(\mathrm{NO}_{3}\right)_{2}$ extractable concentrations of $\mathrm{Cd}$ and $\mathrm{Zn}$. Shoot $\mathrm{Cd}$ and $\mathrm{Zn}$ concentration in Calamagrostis epigejos, the dominant plant species, also decreased in the presence of TBS. The addition of TBS and HA reduced sediment ecotoxicity and improved the growth of the total bacterial population. Hydroxylapatite improved plant species richness and diversity and decreased antioxidant enzymes in C. Epigejos and Urtica dïoica. Collembolan communities did not differ in abundance and diversity between the different treatments.

Keywords : basic slag; Calamagrostis epigejos; dredged sediment; hydroxylapatite; ecotoxicity 
Human activities during the last decades have contaminated canal sediments with various organic and inorganic pollutants. Those of most concern are metal(loid)s, polyaromatic hydrocarbons (PAHs), polychlorinated biphenyls (PCBs), and mineral oils. Polluted sediments in canals may be disposed on land. Indeed, the maintenance of waterways requires dredging on a regular basis to prevent flooding, facilitate navigation, and allow for use of a given water system. European Community policy encourages sediment recovery (Directive 2008/98/EC). Nevertheless, due to the high concentration of pollutants and their potential toxicity, contaminated dredged sediments cannot be used in civil engineering as raw material or the deposit cannot be used to produce valuable biomass. Many treatments are available for contaminated sediments, but relatively few are applicable to metal(loid) pollution. Currently, treatment and reuse of heavily contaminated dredged materials is not a cost-effective alternative to disposal landfill sites (Bert et al., 2009). In the Nord-Pas-de-Calais region (France), which is affected by intensive industrial activities, local authorities are required to manage contaminated landfill sites where large volumes of polluted dredged materials were deposited. The regional division of Voies Navigables de France (VNF) developed a management strategy for its disposal sites. This strategy includes the implementation of an environmental management system which aims to meet best practices and comply with environmental regulation in the field of human health and environment. The VNF is involved in the reclamation of its disposal sites into 'natural' and 'green' zones (Prevost, 2008). Metal immobilization in metal-contaminated sediments at some landfill sites may contribute to this environmental management strategy. 
Metal immobilization aims at (1) changing speciation of trace elements (TE) in the substrate to reduce their soluble and exchangeable fractions, (2) limiting TE-uptake by plants, (3) reducing the direct exposure through soil by reducing metal availability to heterotrophic organisms, resulting in enhanced biodiversity (Vassilev et al., 2004). In situ immobilization of metal(loid)s is achieved by incorporating amendments into the soil, promoting their sorption and precipitation. In addition to immobilization effects, soil amendment can improve soil fertility by increasing $\mathrm{pH}$, organic matter content, microbial activity, and moisture retention, and reducing soil compaction (Vangronsveld et al., 1995, 1996).

The efficiency of amendments is site-specific, depending on various factors among which pollutant types and soil properties (Kumpiene et al., 2008). Numerous soil amendments have been tested in pots, at pilot and field scale, for remediation purposes (Bes and Mench, 2008; Knox et al., 2001; Kumpiene et al., 2008). The effects of Thomas Basic Slag (TBS) and hydroxylapatite (HA) incorporation have only been investigated in batch and pot experiments (Bes and Mench, 2008; Boisson et al., 1999; Friesl et al., 2006; Mench et al., 1994a, 1994b; Mench et al., 2000; Misra and Chaturvedi, 2007; Negim et al., 2010; Panfili et al., 2005). Hydroxylapatite, a mineral from the phosphate group, is the major component of tooth enamel and bone mineral. It is mainly used for medical purposes. Hydroxyapatite powders can be synthesised via numerous production routes, using a range of different reactants. Some processing techniques include wet chemical methods (precipitation), hydrothermal techniques, hydrolysis of other calcium phosphates and sol-gel. Due to its particular properties including the sorption of metallic ions, HA can be useful for the management of contaminated groundwater and soil. The application of $\mathrm{HA}\left[\mathrm{Ca}_{10}\left(\mathrm{PO}_{4}\right)_{6}(\mathrm{OH})_{2}\right]$ to 
contaminated soil immobilizes dissolved $\mathrm{Pb}$ (Ma et al., 1993). Other studies on metal stabilization by phosphorous compounds focused on reduction of plant uptake of metals, as well as reduction of their solubility and mobility (Knox et al., 2001). After HA incorporation into a contaminated soil, the concentrations of exchangeable metals decreased and plant uptake of these elements was reduced (Boisson et al., 1999). However, arsenic uptake by plants increased and there were nutrient deficiencies. Therefore it was concluded that HA application could be effective to immobilize $\mathrm{Zn}$, $\mathrm{Pb}, \mathrm{Cu}$ and $\mathrm{Cd}$ but was inappropriate in the case of mixed metal-arsenic pollution and when potential nutrient deficiencies may occur. Thomas Basic Slag (TBS) is an alkaline by-product of steel industry used as a fertilizer by farmers. It usually increases soil $\mathrm{pH}$ (Bes and Mench, 2008) and contains P, Mn, Mg, and Fe (Panfili et al., 2005). Soil treatment with TBS decreased $\mathrm{Cd}$ and $\mathrm{Zn}$-soluble and $\left(\mathrm{Ca}\left(\mathrm{NO}_{3}\right)_{2}\right)$ exchangeable fractions and reduced Cd concentrations in tobacco shoots (Mench et al., 1994a, 1994b). Zinc availability decreased after TBS addition and this persisted over 5 months without any phytotoxicity (Mench et al., 2000). Bes and Mench (2008) studied the incorporation of $0.25 \%$ and $3.9 \%$ (DW) TBS into Cu-contaminated soils. Based on soil phytotoxicity, $3.9 \%$ TBS was one of the most efficient amendments even though high levels of $\mathrm{Cu}$ remained in the soil solution. Panfili et al. (2005) studied the effect of HA and TBS on $\mathrm{Zn}$ in a metal-contaminated sediment and suggested that the formation of $\mathrm{Zn}$ phosphate contributed to $\mathrm{Zn}$ immobilization.

Plants, bacteria and soil fauna, notably springtails (Collembola), can develop tolerant populations on metal-contaminated soils (Bes et al., 2010; Escarré et al., 2011; Gillet and Ponge, 2003; Lors et al., 2005; Ryan et al., 2004; Tyler et al., 1989; Vangronsveld et al., 1995, 1996). Vegetation reduces contaminant mobility by reducing 
leaching, soil erosion, and improves the aesthetic value of formerly barren areas

119 (Ruttens et al., 2006). The vegetation itself may contribute to metal immobilization in the rhizosphere and through the production of litter (Bouwman and Vangronsveld, 2004). When metal bioavailability and exposure decrease, due to vegetation or amendment or both, sensitive plants, bacteria and soil fauna can develop and participate in turn to the restoration of an ecosystem on contaminated soils (Bouwman et al., 2001; Lock et al., 2003; Lock and Janssen, 2003, 2005; Vangronsveld et al., 1995, 1996). sediment landfill site. The aim was to evaluate the efficiency of TBS and HA incorporation on metal(oid) immobilization. Efficient soil amendments may decrease metal(oid) extractability and shoot metal concentrations. In parallel, the potential adverse or beneficial effects of TBS and HA incorporation were investigated on an site.

2. Materials and methods 

France, $50^{\circ} 23^{\prime} 17^{\prime \prime} \mathrm{N}$ and $3^{\circ} 11^{\prime} 59^{\prime}$ ' $\left.\mathrm{E}\right)$. Three plots of $60 \mathrm{~m}^{2}$ and $40 \mathrm{~cm}$ depth were dug in an uncontaminated soil. These plots were filled with freshly dredged sediments from the nearby Scarpe canal (Pont de Râches). These sediments were contaminated due to past and present non-ferrous metal processing and smelting activities. Two plots were used to assess soil additives. Thomas Basic Slag (TBS) and a synthetic hydroxylapatite (HA), both in powdered forms, were singly incorporated into the sediment at a rate of $5 \%$ and 3\% DW, respectively. TBS was obtained from Cedest ${ }^{\circledR}$ (Mâcon, France) and HA was from Brenntag ${ }^{\circledR}$ (Mülheim/Ruhr, Germany). The purity of HA was certified to 99\% by the supplier. The third plot remained untreated (NT). After TBS and HA incorporation, the treated and untreated plots were mechanically homogenized with a crane shovel for two hours to ensure that the mixture was homogeneous. The plots were air dried for two months to reduce the sediment water content. The three plots were further subdivided into 9 sub-plots of $20 \mathrm{~m}^{2}$ each, resulting in 3 untreated plots (NT), 3 HA-treated plots and 3 TBS-treated plots. Six of these plots were further sown with grasses (Deschampsia cespitosa and Festuca rubra) while the 3 remaining plots remained unplanted. This study reported the work performed on these unsown plots. From mid-spring 2003, spontaneous vegetation started to develop on these plots. Vegetation management (i.e. removal of selected species, harvest, fertilizer addition, and irrigation) was not carried out from this time to March 2007. 
$\mathrm{pH}_{\text {water }}$ and sediment ecotoxicity. Six additional randomly collected samples were taken on each of the plots at a depth of about $20 \mathrm{~cm}$ using a hand auger for bacterial analyses (3 samples/plot) and a corer of $5 \mathrm{~cm}$ diameter for collembolan analyses ( 3 samples / plot). One composite sample per plot was formed with 5 sub-samples randomly collected to determine the other physico-chemical characteristics (particle size, organic 
were determined using an Inductively Coupled Plasma Atomic Emission Spectrometer ICP-AES (Jobin Yvon ${ }^{\circledR}$, Longjumeau, France). To assess the analytical quality, a standard reference sediment material SRM 2704 (Buffalo River Sediment, Standard Reference Material) was subjected to the same protocol. Recoveries were: $100 \%$ for $\mathrm{Cd}, 101 \%$ for $\mathrm{Zn}, 104 \%$ for $\mathrm{Pb}, 90 \%$ for $\mathrm{Cu}$ and $94 \%$ for As.

Soil $\mathrm{pH}$ was measured in 1:5 sediment/soil:water suspension using a glass electrode pH meter (NF ISO 10390, 1994).

Table 1 lists physico-chemical properties of contaminated sediments (NT, HA, TBS) and the uncontaminated soil (CA).

\subsection{Extractable trace element analysis and sediment ecotoxicity}

Extractable sediment metal(oid) concentrations of treated and untreated plots were determined after extraction with $0.01 \mathrm{M} \mathrm{Ca}\left(\mathrm{NO}_{3}\right)_{2}$. Prior to analysis, $20 \mathrm{~g}$ of airdried and sieved sediment were shaken for $48 \mathrm{~h}$ with $40 \mathrm{~mL}$ of $0.01 \mathrm{M} \mathrm{Ca}\left(\mathrm{NO}_{3}\right)_{2}$ solution. Extracts were filtered though a $0.45 \mu \mathrm{m}$ cellulose membrane and metal concentrations were measured using ICP-AES.

Ecotoxicity was assessed by two standardized bioassays: the bacterial Microtox ${ }^{\circledR}$ assay and the algal test, using Vibrio fischeri and Pseudokirchneriella subcapitata as test organisms, respectively. Those two assays were previously shown to be highly sensitive to leachates obtained from dredged materials (Piou et al., 2009). Prior to the bioassays, soil leachates were prepared according to the French standard AFNOR X31210 (1991) and diluted (10 to 90\%) with demineralised water. Ecotoxicity assays were run according to AFNOR T90-320 (1991) and ISO 8692 (1989) standards for Microtox $^{\circledR}$ and algal bioassays, respectively. The half maximum effective concentration 
$213\left(\mathrm{EC}_{50}\right.$, Microtox $^{\circledR}$ bioassay) and the $50 \%$ inhibitory concentration ( $\mathrm{IC}_{50}$, algal bioassay)

214 were derived from dilution-effect curves. When the toxicity of leachates was not

215 sufficient to reach $50 \%$ of effect, EC50\% or $\mathrm{IC}_{50}$ values were indeterminable and the \%

216 of effect observed at the $90 \%$ dilution was then reported.

217 2.5. Plant survey, biodiversity indices and plant analysis

\subsubsection{Plant survey and similarity index}

219 Vascular plants were surveyed in May and June 2007 in all plots using Lambinon et al. (2004) as a standard reference book for plant taxonomy. The total vegetation cover and the cover rate of mosses, herbaceous plants, shrubs and trees were assessed on each plot. Individuals per species and per plot were counted and numbers were related to plot area. Species richness corresponded to the number of species per 224 plot.

A similarity index (Sørensen, 1948) was calculated to compare the composition of vegetation between (i) experimental plots (influence of treatments) and (ii)

227 experimental plots and surrounding biotopes (identification of putative biotopes that may contribute to plot colonization). 
where $p i$ is the species proportion in a community composed of $s$ species. The homogeneity of species distribution was assessed through the regularity index $\mathrm{J}$ of Piélou (1966).

\subsubsection{Plant analyses}

Calamagrostis epigejos, a grass, and Urtica dioica, a forb, were chosen for phytotoxicity and metal content analyses as both herb species were present in all plots and in the control area in sufficient abundance to sample 5 individuals per species of approximately similar size and sufficient biomass to perform analyses. Plant sampling occurred in June 2007.

\subsubsection{Chlorophyll fluorescence}

The fluorescence of chlorophyll a was measured on dark-adapted leaves of $C$. epigejos and $U$. dioica submitted to a saturating light pulse using a portable chlorophyll fluorimeter (Handy-PEA, Hansatech Instruments ${ }^{\circledR}$, Norfolk, UK). Basal fluorescence (F0) and maximum fluorescence (Fm) values were used to derive Fv/Fm ratio (maximum photochemical efficiency of PSII), with the variable fluorescence Fv=FmF0.

\subsubsection{Antioxidant enzymes}

Leaves from both plant species were collected from CA, NT, HA and TBS plots and immediately transferred to polypropylene tubes then frozen in liquid nitrogen. At the laboratory, leaf samples were crushed manually in a $125 \mathrm{mM}$ phosphate buffer at $\mathrm{pH}$ 7.8 by using a porcelain mortar placed on ice. After centrifugation (15 $000 \mathrm{~g}$ for $10 \mathrm{~min}$ at $4^{\circ} \mathrm{C}$ ), the supernatant was used to determine antioxidant enzyme activities. 
255 Superoxide dismutase (SOD), catalase (CAT), ascorbate peroxidase (APX), guaiacol 256 peroxidase (GPX), and glutathione reductase (GRD) activities were measured according

257 to methods described by Dazy et al. (2008). The protein concentration was determined 258 in plant extracts (Bradford, 1976); enzyme activity levels were expressed in $259 \mu \mathrm{moles} / \mathrm{min} / \mathrm{mg}$ protein excepted for SOD for which one unit of activity corresponded to the amount of enzyme causing 50\% inhibition of absorbance readings by comparison to control tubes lacking enzymes.

\subsubsection{Elemental concentrations in plant shoots}

Plant shoots were carefully washed (3 times) with distilled water and oven-dried at $40^{\circ} \mathrm{C}$ until constant weight. Weighed aliquots $(0.5 \mathrm{~g} \mathrm{DW})$ were wet digested in $10 \mathrm{~mL}$ $\mathrm{HNO}_{3}(65 \%)$ using a microwave digester (Mars Xpress) according to the following program: 3 min to reach $100{ }^{\circ} \mathrm{C}, 2 \mathrm{~min}$ to reach $140{ }^{\circ} \mathrm{C}, 2$ min to reach $160{ }^{\circ} \mathrm{C}, 2 \mathrm{~min}$ to reach $180{ }^{\circ} \mathrm{C}$ and $20 \mathrm{~min}$ at $180^{\circ} \mathrm{C}$. Solutions were filtered to $<0.45 \mu \mathrm{m}$ (Whatman filter) and concentrations of $\mathrm{Cd}, \mathrm{Zn}, \mathrm{Pb}, \mathrm{Cu}, \mathrm{As}, \mathrm{Ca}, \mathrm{Fe}, \mathrm{Mg}, \mathrm{Mn}, \mathrm{P}, \mathrm{Na}, \mathrm{K}$ and $\mathrm{Al}$ were analyzed using ICP- AES (VARIAN 720 AES-ICP, Ulys ${ }^{\circledR}$, France). Blanks and certified reference material (trace elements in hay, IAEA V10, International Atomic Energy Agency, Vienna, Austria) were included for quality control. Recoveries were: $100 \%$ for $\mathrm{Ca}, 91 \%$ for $\mathrm{Cu}, 79 \%$ for $\mathrm{Fe}, 113 \%$ for $\mathrm{Mg}, 91 \%$ for $\mathrm{As}, 89 \%$ for $\mathrm{Mn}$ and $\mathrm{Pb}$, $105 \%$ for K, $89 \%$ for $\mathrm{Na}, 118 \%$ for $\mathrm{P}, 87 \%$ for $\mathrm{Zn}, 93 \%$ for $\mathrm{Cd}$ and $67 \%$ for $\mathrm{Al}$.

\subsection{Collembola identification and gut content observation}

After sampling at a depth of $20 \mathrm{~cm}$, considering that the whole collembolan 
(CA) samples were embedded in polythene bags then transported to the laboratory. The extraction of arthropods started on the same day using the dry funnel (Berlese) method (Edwards and Fletcher, 1971) and was completed within 7-10 days. The daytime maximum temperature averaged $25-30{ }^{\circ} \mathrm{C}$. Animals were collected and preserved in ethyl alcohol until sorting and identification. Sorting was done in alcohol under a dissecting microscope at x 20 magnification. All springtails were mounted in chlorallactophenol then observed in a light microscope under phase contrast at x 400 magnification. Identification was done at the species level using keys by Bretfeld (1999), Fjellberg (1998), Gisin (1960), Hopkin (2000), Jordana et al. (1997), Potapov (2001) and Zimdars and Dunger (1994), Gut contents were observed by transparency and classified in 8 categories using morphological features observable in phase contrast light microscopy at $\mathrm{x} 400$ magnification, and were counted according to the method devised by (Gillet and Ponge, 2003, 2005): algae, animal remains, bacteria, melanised and hyaline hyphae, fungal spores, holorganic humus, hemorganic humus, to which empty guts were added. The examination of gut contents may elucidate the composition of horizons in which the animals were living (Ponge, 2000). We sought to determine when toxicity forced the organisms to move to horizons in which they do not normally live or delete some food resources from their current diet (Gillet and Ponge, 2003).

\subsection{Bacterial analyses}

Sediment samples (NT, HA and TBS) were collected in polythene bags then transported to the laboratory. After homogenization, samples were maintained at $4{ }^{\circ} \mathrm{C}$ before performing bacterial analyses. The enumeration of total sulphur-oxidising bacteria (SOB) was carried out on $\mathrm{Nunc}^{\circledR}$ Delta (Nalge Nunc International ${ }^{\circledR}$, Roskilde, Denmark) microplates of 96 wells (8 lines x 12 columns), on which each well contained 
$250 \mu \mathrm{L}$ of specific medium. Nutrient Broth $^{\circledR}$ (Difco ${ }^{\circledR}$, Detroit, USA) medium (diluted to 1/10), added to fungicidal cyclohexamide solution $\left(0.2 \mathrm{~g} \mathrm{~L}^{-1}\right)$, was used for total bacterial count. The medium used to enumerate neutrophilic SOB contained $5 \mathrm{~g}$

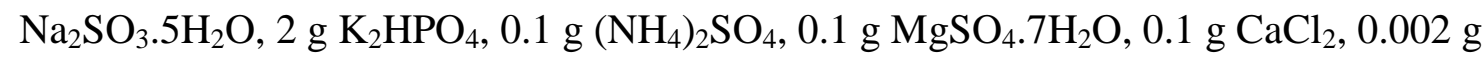
$\mathrm{FeCl}_{3} .6 \mathrm{H}_{2} \mathrm{O}, 0.005 \mathrm{~g} \mathrm{MnSO}_{4} .4 \mathrm{H}_{2} \mathrm{O}$ and $3 \mathrm{ml}$ bromocresol purple $\left(\mathrm{c}=0.02 \mathrm{~g} \mathrm{~L}^{-1}\right)$. The $\mathrm{pH}$ of the medium was initially adjusted to $\mathrm{pH} 6.5$ with $\mathrm{NaOH}$. For acidophilic SOB, the medium, which contained $1.5 \mathrm{~g} \mathrm{KH}_{2} \mathrm{PO}_{4}, 0.1 \mathrm{~g} \mathrm{CaCl}_{2}, 0.1 \mathrm{~g} \mathrm{MgCl}_{2} . \mathrm{H}_{2} \mathrm{O}$, and $0.1 \mathrm{~g}$ $\mathrm{NH}_{4} \mathrm{Cl}$, was combined with $3 \mathrm{ml}$ of bromocresol green $\left(\mathrm{c}=0.02 \mathrm{~g} \mathrm{~L}^{-1}\right)$. The $\mathrm{pH}$ was initially adjusted to 4.5 with $\mathrm{HCl}$. A suspension containing $10 \mathrm{~g}$ of dry soil and $50 \mathrm{ml}$ of Ringer solution was mixed in a Waring blender for $1.5 \mathrm{~min}$ at high speed. After decantation, the solution was successively diluted with Ringer solution to $10^{-1}-10^{-8}$ (Ramsay, 1984). Each well was inoculated with $25 \mu 1$ of solution. The wells of the eight lines corresponded to the eight tested dilutions. Each sample was inoculated in the wells of three columns and a column was not inoculated to control the sterility of the medium. As each microplate had twelve columns, only one microplate was used for the three samples of a given plot. The inoculated plates were incubated at $30^{\circ} \mathrm{C}$ for 15 days and then the coloured products were measured. Bacteria were counted using the Most Probable Numbers (MPN) method (De Man, 1977). Sulphate-reducing bacteria (SRB) were counted in tubes containing a solid medium specific to SRB (American Petroleum Institute, Washington, DC) (Lors et al., 2004).

\subsection{Statistical analyses}

A one-way ANOVA was used to detect treatment effects on metal concentrations, Fv/Fm ratio, antioxidant enzyme activities, species distribution, biodiversity indices, distribution of gut contents and bacterial numbers. When ANOVA 
was significant, mean values were compared with post-hoc multiple-comparison procedures. When the sample weight was too low and variance homogeneity was not fulfilled, a non-parametric statistical test followed by a multiple-comparison procedure was performed. Correlation analysis, using Pearson product-moment correlation coefficient, was performed between metal concentrations and antioxidant enzymes activities in leaves. Statistica v7 (StatSoft Inc.) was used for bacterial calculations whereas XLSTAT $^{\circledR}$ (Addinsoft $^{\circledR}$, Paris, France) was used for springtail calculations. All other statistics were made with PASW statistics 18.

A semi-quantitative method was specially devised to make an overall assessment of beneficial or adverse effects of soil amendment (HA and TBS) addition on dredged sediments. For this purpose, the treatments (NT, HA, TBS) were ranked 1 to 3 , a value of 1 being attributed to the treatment that maximized variables describing optimal features of plant, faunal and microbial communities (i.e. vegetation succession state, species richness, species diversity, equitability, abundance) and plant Fv/Fm ratio, or minimized those describing metal mobility, ecotoxicity, plant metal concentration and antioxidant enzyme activity,. Some variables cannot be taken into account in these calculations, either because they may respond to other factors than soil toxicity (acid vs neutral sulphur-oxidizing bacteria, collembolan gut contents, vegetation composition, $\mathrm{pH}$ ), or because they do not differ significantly among treatments (plant Fv/Fm ratio for C. epigejos). Ranks were then averaged among the different variables which had been kept for the calculations. Overall differences between the three treatments NT, HA and TBS were then tested by a sign-test, using ranks as unit values.

\section{Results}


Extractable $\mathrm{Pb}$ and $\mathrm{As}$ concentrations in all plots were below quantification

351 limits (0.07 and $0.1 \mathrm{mg} \mathrm{kg}^{-1} \mathrm{DW}$ for $\mathrm{Pb}$ and $\mathrm{As}$, respectively). Cadmium and $\mathrm{Zn}$ showed

352

353 a similar pattern with higher $0.01 \mathrm{M} \mathrm{Ca}\left(\mathrm{NO}_{3}\right)_{2}$-extractable concentrations in the NT plot than in the TBS-treated plot, while intermediate values were found in the HA-treated plot (Table 2). Expressed as percentages of the total metal concentrations, extractable $\mathrm{Cd}$ and $\mathrm{Zn}$ represented 0.14 and $0.07 \%$, respectively, in the TBS-treated plot, whereas they represented 0.37 and $0.76 \%$ in the NT plot and 0.31 and $0.61 \%$ in the HA-treated plot. For $\mathrm{Cu}$, no significant differences occurred across the plots.

Sediment leachates were moderately toxic to the bacteria $V$. fischeri since no $\mathrm{EC}_{50}$ could be determined. Considering the $\%$ of effect measured at the $90 \%$ dilution, the ecotoxicity of sediment leachates could be ranked in the following order NT $>\mathrm{HA}>$ TBS (Table 2). Sediment leachates were more toxic to Algae, especially those prepared from NT and HA ( $\mathrm{IC}_{50}$ values being 12.8 and $19.2 \%$, respectively). TBS sediment leachate had only a slight inhibitory effect on Algae.

\subsection{Plant survey, plot similarity, source of colonization and element concentrations}

The composition of the plant community was influenced by the treatments of the plots as shown by plant survey and the number of individuals per species and per surface (Table 3). The TBS plot was mainly colonized by herbaceous plants while HA and NT plots were dominated by shrubs. The maximum height of shrubs was higher in HA plot than in NT plot. The TBS plot had the lowest plant species richness $(n=14)$. 

highest plant diversity with a more homogeneous species distribution while TBS and NT plots showed a lower diversity and at least one species that dominated the overall community (Table 3). for TBS and 3 species for NT. Among Poaceae, only C. epigejos was present on all plots. Calamagrostis epigejos was more present on the NT plot (46.9\%), than on TBS (30\%) and HA plots (19.9\%). On all plots, other plant species were abundant: Carex hirta $(11.5 \%)$ and Glechoma hederacea $(11.7 \%)$ on the NT plot, Betula pendula $(12.7 \%)$ and $G$. hederacea $(22.8 \%)$ on the HA plot, and Phalaris arundinacea $(32.1 \%)$, Galium aparine (16.4\%) and Epilobium angustifolium (11.7\%) on the TBS plot. The second most abundant family was Asteraceae with three species. At least two Asteraceae were present on all plots. Perennial species dominated the three group communities. Plant species were native to the Nord-Pas-de-Calais region with no clear specificity linked to sediment traits except for some plants showing hygrophilic characteristics (e.g. Eupatorium cannabinum, C. hirta, Carex cuprina, P. arundinacea, Salix alba). between plots and surrounding biotopes, indicated that $85 \%$ of plant species were common between NT and HA plots whereas the TBS plot showed $60 \%$ and $57 \%$ species similarity with HA and NT plots, respectively (data not shown). The surrounding biotopes consisted of a slag heap, a ruderal zone, a canal bank, and an agricultural land. A similarity index indicated that the plant colonizers of the NT and HA plots mainly originated from the slag heap, with 45 and $41 \%$ of species similarity. 
This result agreed with the direction of the south-easterly prevailing wind and the seed shadow colonization hypothesis (Clark et al., 2005), as the slag heap was situated southeast from the plots. The TBS plot showed less similarity with the slag heap (33\%).

The concentrations of the chemical elements were measured in C. epigejos and U. dioica as both species were sampled in all plots (Table 4). Their shoot $\mathrm{Pb}$ and $\mathrm{As}$ concentrations were below quantification limits ( 1 and $0.5 \mathrm{mg} \mathrm{kg}^{-1}$ for $\mathrm{Pb}$ and $\mathrm{As}$, respectively). Shoot $\mathrm{Cd}$ and $\mathrm{Zn}$ concentrations for both species and $\mathrm{Cu}$ concentration for U. dioica were lower in CA than in the three treatments. The shoot $\mathrm{Cd}$ concentration was the lowest in $C$. epigejos grown on TBS whereas for $U$. dioica it did not differ across treatments. Shoot $\mathrm{Zn}$ concentration was the lowest in C. epigejos grown on TBS. The highest shoot $\mathrm{P}$ and $\mathrm{K}$ concentrations were measured in $U$. dioica grown on TBS. No other significant effect of TBS treatment on metal concentration was observed. The HA treatment did not decrease shoot $\mathrm{Cd}$ and Zn concentrations of $C$. epigejos and $U$. dioica compared to NT but increased shoot $\mathrm{Cu}$ in C. epigejos. Shoot $\mathrm{Mg}, \mathrm{Na}$, and $\mathrm{Al}$ concentrations in C. epigejos and shoot Fe concentration in $U$. dioica were higher in the HA plot than in the NP plot. The HA treatment did not influence other shoot element concentrations.

\subsection{Antioxidant enzyme activities and chlorophyll fluorescence of leaves}

Unstressed plants typically exhibit Fv/Fm ratios of 0.8-0.83 (Laposi et al., 2009), which was the case for C. epigejos on all plots (Fig. 1). For all antioxidant enzymes, lowest activities were determined in CA plants. In untreated sediment (NT), C. epigejos enzymes were significantly increased 1.2 to 3 fold depending on the enzyme considered. 
419 For plants collected on HA plots, the activity of SOD, CAT, and GRD were similar to 420 CA values, except APX which remained higher. For GPX, the HA treatment had no significant effect. This enzyme was less influenced than the others by the composition

422 of the NT sediment since its activity only increased by a factor of 1.2 compared to plants harvested on CA plots. Plant enzymes responded differently to the TBS treatment. For SOD, CAT and APX, activities levels were not influenced since their values did not differ significantly from corresponding values in NT plants. GPX and GRD were both affected by TBS treatment, but in opposite ways, since GPX increased by comparison to NT values while GRD decreased.

Urtica dioica collected from CA and HA plots, and to a lesser extend NT plots, had all Fv/Fm ratios around 0.8 (Fig. 2). For TBS-plants, the Fv/Fm ratios were significantly lower. As noted for C. epigejos, for all antioxidant enzymes, the lowest activities were found for CA plants. For the untreated sediment (NT), U. dioica enzymes significantly increased by a factor 3 to 5 . The HA and TBS treatments had opposite effects on antioxidant enzymes. All tested enzyme activities in $U$. dioica leaves decreased for HA compared to NT and tended to recover CA values. However, differences between HA and CA plants remained significant for SOD, APX and GPX activities. In contrast, TBS plants still exhibited high enzyme activities, similar to NT values (e.g. APX and CAT) or even higher (e.g. SOD, GPX, and GRD).

\subsection{Correlations between shoot element concentrations and antioxidant} enzyme activities

A correlation analysis was performed, between shoot element concentrations in C. epigejos and $U$. dioica and their antioxidant enzyme activities in leaves, to reveal significant linear relationships (Table 5). All enzyme activities negatively correlated 
with shoot $\mathrm{Cd}$ concentration in C. epigejos. Manganese concentrations were positively

444 correlated with 4 out of the 5 enzyme activities whereas $\mathrm{Cu}, \mathrm{Zn}, \mathrm{Mg}$, and $\mathrm{Na}$

445

446

447

concentrations were correlated with GRD. For $U$. dioica, no relationship was found between shoot $\mathrm{Cd}$ concentration and any of the enzyme activities, but all enzyme activities were positively correlated with shoot $\mathrm{Cu}, \mathrm{Zn}, \mathrm{P}$, and $\mathrm{K}$ concentrations.

\subsection{Collembolan diversity and gut contents}

A total of fourteen species were found in the four areas (Table 6). Neither total abundance nor biodiversity indices (species richness, Shannon index, equitability) showed significant differences between treatments. However, the TBS plot tended to harbour more specimens and species than NT and HA plots and CA. In the NT plot, there was no decrease in any of the four biodiversity indices when compared to CA, with a mean abundance of 20 specimens per core sample, shared between four species. At the species level, Friesea truncata was only present in the TBS samples.

The only significant effect on the gut contents of Collembola (Fig. 3) was an increase in the percent of specimens with hyaline fungal hyphae, which increased in all cores sampled in the HA plot, reaching an average of $16 \%$ compared to less than $3 \%$ for the other treatments. Hemorganic humus (amorphous organo-mineral matter) was dominant everywhere, indicating that the sediments (treated or not) were consumed by springtails, in particular by the dominant species Mesaphorura florae.

\subsection{Total and specific bacterial numbers}

The total bacterial population in all plots varied from $10^{7}$ to $10^{8}$ bacteria $\mathrm{g}^{-1}$ dry sediment, and was similar to that usually found in unpolluted topsoils (Robert, 1996; 
Taylor et al., 2002) (Table 7). However, in the TBS plot, the total bacterial population (in $10^{8}$ bacteria. $\mathrm{g}^{-1}$ dry soil) was significantly higher (1.7) than in the NT plot $(0.21)$. In all plots, neutrophilic sulphur-oxidising bacteria (NSOB) were the most abundant group, with about $10^{5}$ bacteria $\mathrm{g}^{-1}$ dry sediment, whereas acidophilic sulphuroxidising bacteria (ASOB) were the least abundant group with about $10^{3}-10^{4}$ bacteria $\mathrm{g}^{-}$

${ }^{1}$ dry sediment. The amendments did not modify the size of these bacterial populations. The sulphate-reducing bacterial microflora (SRB) was about $10^{1}-10^{2}$ bacteria $\mathrm{g}^{-1}$ dry sediment and was of the same order of magnitude in all plots.

.

\title{
3.7. Integration of data from the ecotoxicity battery
}

\begin{abstract}
Averaging ranks of all variables selected for the synthetic assessment of treatment effect (see Material and methods) indicated that TBS and HA exhibited similar favourable effects on the ecosystem when compared to the untreated sediment (NT) (Table 8). HA and TBS treatments ranked significantly above NT (one-sided ttests, $\mathrm{P}=0.001$ and 0.011 , respectively) while they did not differ from each other (twosided t-test, $\mathrm{P}=0.797)$.
\end{abstract}

\section{Discussion}

Although the TBS application rate and the soil type used in this study differed from those investigated in other works, our results are broadly similar for $\mathrm{Zn}$ and $\mathrm{Cd}$. The incorporation of TBS (5\% DW) into the metal contaminated sediment decreased the $0.01 \mathrm{M} \mathrm{Ca}\left(\mathrm{NO}_{3}\right)_{2}$-extractable $\mathrm{Cd}$ and $\mathrm{Zn}$ fractions and shoot $\mathrm{Cd}$ and $\mathrm{Zn}$ concentrations of C. Epigejos (Tables 2 and 4), confirming previous findings (Mench et al., 1994a, 1994b, 2000). The TBS incorporation into a Cd-Zn-contaminated soil, reduced both the 
$\mathrm{Ca}\left(\mathrm{NO}_{3}\right)_{2}$ extractability of $\mathrm{Cd}$ and $\mathrm{Zn}$ and their contents in tobacco shoots (Mench et al., 1994a, 1994b). In addition, TBS added into a Zn-contaminated soil increased soil pH, decreased extractable $\mathrm{Zn}$ and shoot $\mathrm{Zn}$ concentration in ryegrass, 3 and 5 months after soil treatment (Mench et al., 2000). Contrary to TBS, HA incorporation (3\% DW) into

492 the sediment did not decrease significantly $\mathrm{Cd}$ and $\mathrm{Zn}$ extractability nor $\mathrm{Cd}$ and $\mathrm{Zn}$ concentrations in plants (Tables 2 and 4). These results were not consistent with those of Boisson et al. (1999) who found a decrease of extractable Cd and $\mathrm{Zn}$ and metal concentrations in maize when compared to the untreated soil and with increasing HA application rate $(0.5,1$ and $5 \% \mathrm{DW})$. mobilization was not observed either in the presence of HA or TBS (Table 2). No amendment effect was recorded for $\mathrm{Cu}$ (Tables 2 and 4) whereas TBS incorporation ( 0.25 and $3.9 \% \mathrm{DW})$ into a $\mathrm{Cu}$ contaminated soil decreased $\mathrm{Cu}$ concentrations in the primary leaves of bean (Bes and Mench, 2008). mobility and transfer to the plants. We hypothesise that $\mathrm{Zn}$ - and Cd-phosphates were precipitated, thereby immobilizing these elements in a non-available form as suggested by Panfili et al. (2005) who studied Zn speciation in the same metal-contaminated sediment treated with TBS. In our field experiment, the low efficiency of HA compared

507 to TBS may be explained by the low solubility of HA at neutral pH (Table 1). As suggested by Miretzky and Fernandez-Cirelli (2007), the solubility of the phosphate phase is necessary for successful in situ treatment, metal immobilization by phosphorus being limited or inefficient when the matrix is neutral or alkaline. 
As the essential nutrient concentrations did not decrease in plant shoots (Table

512 4), our results suggested that neither TBS nor HA led to deficiency problems in the

513

514

515

516

517

518

519

520

521

522

523

524

525

526

527

528

529

530

531

532

533

534 tested plant species. In the presence of HA (5\% DW), Boisson et al. (1999) reported a Mn-deficiency in maize. Neither treatment promoted the uptake of essential nutrients such as $\mathrm{Ca}$ except in the case of $U$. dioica where shoot $\mathrm{P}$ and $\mathrm{K}$ concentrations were increased by TBS addition. In primary leaves of bean, Ca concentration was enhanced in the presence of TBS whereas P concentration was not promoted (Bes and Mench, 2008; Negim et al., 2010).

In our study, sediment ecotoxicity was reduced by the incorporation of TBS and HA, TBS being the most efficient amendment.

At excessive concentrations in the soil solution, $\mathrm{Cd}, \mathrm{Cu}, \mathrm{Pb}$ and $\mathrm{Zn}$ exert toxic effects on plants, including alterations in photosynthetic and respiration processes or inhibition of plant growth. They may also stimulate the formation of reactive oxygen species (Dazy et al., 2009). To prevent oxidative damage, plant cells usually use enzymatic protection mechanisms, such as superoxide dismutase, catalase, and peroxidases, and metabolites such as ascorbate and glutathione (Dazy et al., 2008). Following amendment of the soil, a decrease in phytotoxicity and a recovery in plant antioxidant defence to control values are expected as a result of metal-immobilization processes (Ruttens et al., 2006; Vangronsveld et al., 1995, 1996). In the NT plot, all antioxidant enzyme activities of both plant species were increased compared to the CA plot, indicating that the plants suffered from oxidative stress. The increase in shoot $\mathrm{Zn}$ and $\mathrm{Cu}$ concentrations were consistent with enzymatic activity increases, suggesting that these metals accounted for the stress response recorded in plants growing on untreated dredged sediment. This was not the case for $\mathrm{Cd}$, as no correlation for $U$. 
dioica and no positive correlation for $C$. epigejos were found. The addition of HA permitted an almost total recovery of antioxidant enzyme activities to CA values, whereas the addition of TBS did not. Thus, HA was a better amendment for keeping the stress responses of plants at a low level. Levels of chlorophyll fluorescence (Fig. 1 and Fig. 2) indicated that the plants were not stressed on NT, HA and TBS plots. There are few studies that report the effect of TBS on phytotoxicity and an absence of studies on the effect of HA on phytotoxicity. After the incorporation of TBS (0.25\% and 3.9\%) into a $\mathrm{Cu}$-contaminated soil, the chlorophyll density of primary leaves of bean decreased and guaiacol-peroxidase activity in roots fell to control level (Bes and Mench, 2008). In another experiment, TBS added to a Zn-contaminated soil restored guaiacolperoxidase activity of the primary leaves in beans to control values (Mench et al., 2000). Most of the plant species present on the NT plot were also observed on the surrounding uncontaminated biotopes (slag heap and ruderal zone), which were similarly firstly devoid of vegetation. Thus, colonization of the NT plot was not limited by the total metal concentration in the sediment, which is consistent with previous findings (Escarré et al., 2011). Madejon et al. (2006) showed that the application of amendments to a metal contaminated soil improved spontaneous colonization and establishment of early-successional plants. In our study, all plots were covered by dense vegetation (close to $100 \%$ ) but differed in plant community composition and biodiversity descriptors. This may indicate that the amendment application was not a key factor for colonization and establishment of spontaneous vegetation but an important factor that could modify vegetation composition and dynamics. The addition of TBS or HA to the sediment influenced the dynamic process of plant colonization, the three plots showing differences in composition of the plant community. The large 
559 increase in $\mathrm{pH}$ following addition of TBS to the sediment (7.4 to 10.2 in May 2002), 560 compared to the modest increase (7.4 to 7.7 in May 2002) in the presence of HA, may

561 be responsible for the main changes in plant community in the TBS plot compared to

562 other plots. Only spontaneous vegetation that is able to tolerate alkaline pHs could

563 colonize this plot. Elevated $\mathrm{pH}$ favours the establishment of herbaceous rather than

564 woody species (Skousen et al., 1994). Five years after the single application, the pH in

565 the TBS-treated sediment decreased to 7.7 while pHs of NT and HA plots were 7.0 and

566 7.3, respectively (Table 1). This decrease may be sufficient to favour the establishment

567 of $B$. pendula in the next few years, as two seedlings were noticed in the TBS plot.

568 Calamagrostis epigejos is known as a competitive social grass able to arrest plant

569 succession by forming extended dense areas (Prach, 2003). At maturity, it can reach 1.5

$570 \mathrm{~m}$ in height thereby shading smaller or slowly-growing plant species (Rebele and

571 Lehmann, 2001). As the higher rate of C. epigejos was recorded on the TBS plot, this

572 plant would contribute to the maintenance of early stage succession vegetation on this

573 plot.

The highest level of plant species richness was found in the presence of HA (26

575 species out of 16 families) compared to the NT plot (21 species out of 14 families). In

576 contrast, TBS did not favour species richness as it accounted for the least value (14

577 species out of 9 families). This is paradoxical since the TBS plot had the lowest

578 concentrations of extractable $\mathrm{Zn}$ and $\mathrm{Cd}$ and the lowest sediment ecotoxicity, but the

579 competitive exclusion of plants by C. epigejos possibly outweighed effects of decreased 580 toxicity.

581 Concerning diversity indices, our H' values were much higher than those given 582 by Conesa et al. (2007) and Dazy et al. (2008) who studied plant communities growing 
respectively on $\mathrm{Zn}-\mathrm{Pb}$-contaminated tailings and experimental plots filled with a multicontaminated soil. However, such comparisons of H'values may be confounded by different soil and pollution parameters as well as the time elapsed after colonization.. For Dazy et al. (2008), the survey was performed after 14 months of colonization whereas in this study the survey was done 5 years after colonization.

The influence of metal contamination on natural springtail communities has been documented (Bengtsson and Rundgren, 1988; Chauvat and Ponge, 2002; Gillet and Ponge, 2002, 2003; Lock et al. 2003; Strojan, 1978). In these works, no major adverse effects of metal contamination were recorded. Springtails were abundant even in highly contaminated sites, which indicates the resistance of this group to toxic effect of metals and other environmental stresses (Hopkin, 1997), exemplified by high $\mathrm{EC}_{50}$ values in Folsomia candida reproduction test at $20{ }^{\circ} \mathrm{C}$ for $\mathrm{Cd}\left(590 \mu \mathrm{g} \cdot \mathrm{g}^{-1}\right), \mathrm{Cu}(700$ $\left.\mu \mathrm{g} \cdot \mathrm{g}^{-1}\right), \mathrm{Zn}\left(900 \mu \mathrm{g} \cdot \mathrm{g}^{-1}\right)$ and $\mathrm{Pb}\left(2790 \mu \mathrm{g} \cdot \mathrm{g}^{-1}\right)$ (Sandifer and Hopkin, 1997). In our study, neither total abundance nor biodiversity indices showed significant differences between NT plot and CA, showing the normal colonization by springtails of the NT plot. The addition of TBS and HA did not change the abundance or biodiversity indices, showing no effect of these amendments on the springtail community. Some effect may have been expected on the TBS plot as Lock et al. (2003) reported a significant negative relationship between the metal extractable fraction $\left(0.01 \mathrm{M} \mathrm{CaCl}_{2}\right.$ solution $)$ and the number of springtail species. In our study, the gut content analyses showed that untreated and amended dredged sediments were consumed by springtails (Fig. 3).

In soils that are highly contaminated with metal(loid)s, a lower number of bacteria than in uncontaminated soil could be expected, as a result of the harmful effects of the contaminants on soil bacterial activity, especially bacterial respiration and soil 
bacterial biomass (Renella et al., 2005; Sobolev and Begonia, 2008). In our study, the total bacterial population in the NT plot was similar to that usually found in unpolluted topsoils (Taylor et al., 2002).

The addition of TBS to the soil improved the total bacterial population, probably as a consequence of the low $\mathrm{Cd}-\mathrm{Zn}$-extractable fraction on this plot.

Bacteria play an important role in increasing or decreasing metal availability, notably in sediments (Bert et al., 2009). Bioleaching of metals is caused by sulphuroxidising bacteria (SOB) whereas anaerobic sulphate-reducing bacteria (SRB) can precipitate metals. Neutrophilic and acidophilic SOB were found in similar numbers in all plots, showing no amendment effect. In all sediment plots, neutrophilic SOB were more numerous than acidophilic SOB, due to soil $\mathrm{pH}$ close to neutrality (Table 1). The moderate development of acidophilic SOB was consistent with the results of Lors et al. (2004) who reported an acidophilic sulphur-oxidising population of about $10^{4}$ bacteria $\mathrm{g}^{-1}$ dry soil in a similar sediment. These results indicated that metals might be released in the case of metal sulphide availability.

Sulphate-reducing bacteria were present in the same low range in the three sediment plots, showing no amendment effect (Table 7). The low amount of SRB may be explained by the sampling performed on the first $20 \mathrm{~cm}$ depth layer corresponding to aerobic conditions, not favourable to the growth of SRB that are strictly anaerobic. However, during wet periods, the saturation of the soil pore system might induce anoxic conditions that would promote the size of the SRB community, leading to increased metal sulphide content.

\section{Conclusions}


contaminated sediment landfill site to evaluate their effects on metal extractability, extractable fraction of $\mathrm{Cd}$ and $\mathrm{Zn}$. In contrast, $\mathrm{HA}$ did not decrease $\mathrm{Cd}$ and $\mathrm{Zn}$ extractability. TBS at a rate of 5\% DW was effective in $\mathrm{Cd}$ and $\mathrm{Zn}$ immobilization, did not cause any nutrient imbalance or sediment ecotoxicity, and improved the bacterial activity.

However, TBS application had either no influence or a negative effect, on maximum photochemical efficiency of PSII and antioxidant enzymes in plants. The bioavailability of the compound(s) responsible for those biological responses was not decresead by TBS treatment. Even if plants successfully colonized the TBS plot, they remained under stress. to NT, (ii) the better influence of HA on vegetation development and physiological welfare (as measured by PSII measurements and antioxidant enzymes), (iii) the better influence of TBS on sediment ecotoxicity, metal immobilization, microbial population and $\mathrm{Cd}-\mathrm{Zn}$ accumulation in C. epigejos. The choice of using metal immobilization with TBS rather than HA as a tool in the management of dredged sediment landfill sites will depend on the objectives of such strategy, i.e. to limit metal transfer and sediment ecotoxicity or to favour plant diversity and welfare. Realising both objectives requires a

652 study of a mixture of both soil amendments. 
Acknowledgements

This study was financially supported through the Programme de Recherches

Concertées (PRC) Environnement-Ecotoxicité: Meresbio, étude des mécanismes de la

657 restauration de la biodiversité sur un site contaminé par les métaux, by the Contrat de Plan

658 Etat/Région Nord-Pas-de-Calais and the European FEDER (ANR - ex.FRT 2005 - action

659 Régionale - CPER DT n 15006 Décision n²005 - CPER - Nord - 176). We thank the

660 anonymous reviewers for improving the manuscript and B. Robinson for providing

661 language assistance.

662

663

References

664

AFNOR T90-320, 1991. Testing water-determination of the inhibition of the light

665 emission of Photobacterium phosphoreum. Association Française de

666 Normalisation, Paris.

667

AFNOR X31-210, 1992. Waste - Leaching of waste. Association Française de

668 Normalisation, Paris. 1138. 
678 Bes, M.C., Mench, M., Aulen, M., Gaste, H., Taberly, J., 2010. Spatial variation of

679

680

681

682

683

684

685

686

687

688

689

690

691

692

693

694

695

696

697

698

699

700 plant communities and shoot $\mathrm{Cu}$ concentrations of plant species at a timber treatment site. Plant and Soil 330, 267-280.

Boisson, J., Ruttens, A., Mench, M., Vangronsveld, J., 1999. Evaluation of hydroxyapatite as a metal immobilizing soil additive for the remediation of polluted soils. I. Influence of hydroxyapatite on metal exchangeability in soil, plant growth and plant metal accumulation. Environmental Pollution 104, 225233.

Bouwman, L.A., Bloem, J., Römkens, P.F.A.M., Boon, G.T., Vangronsveld, J., 2001. Beneficial effects of the growth of metal tolerant grasses on biological and chemical parameters in copper and zinc contaminated sandy soils. Minerva Biotecnologica 13, 19-26.

Bouwman, L.A., Vangronsveld, J., 2004. Rehabilitation of the nematode fauna in a phytostabilized heavily zinc-contaminated, sandy soil. Journal of Soils and Sediments 4, 17-23.

Bradford, M.M., 1976. A rapid and sensitive method for the quantification of microgram quantities of protein utilizing the principle of protein-dye binding. Analytical Biochemistry 72, 248-254.

Bretfeld, G., 1999. Synopses on Palaearctic Collembola. II. Symphypleona. Abhandlungen und Berichte des Naturkundemuseums Görlitz 71, 1-318.

Chapin, F.S. III, Walker, L.R., Fastie, C.L., Sharman, L.C., 1994. Mechanisms of primary succession following deglaciation at Glacier Bay, Alaska. Ecological Monographs 64, 149-175. 
Chauvat, M., Ponge, J.F., 2002. Colonization of heavy metal-polluted soils by collembola : preliminary experiments in compartmented boxes. Applied Soil Ecology 21, 91-106.

Clark, C.J., Poulsen, J.R., Bolker, B.M., Connor, E.F., Parker, V.T., 2005. Comparative seed shadows of bird-, monkey-, and wind-dispersed trees. Ecology 86, 26842694.

Conesa, H., M., Garcia, G., Faz, A., Arnaldos, R., 2007. Dynamics of metal tolerant plant communities' development in mine tailings from the Cartagena-La Union Mining District (SE Spain) and their interest for further revegetation purposes. Chemosphere 68, 1180-1185.

Dazy, M., Jung, V., Férard, J.F., Masfaraud, J.F., 2008. Ecological recovery of vegetation at a former coke-factory industrial wasteland: role of plant antioxidant enzymes and possible implications in site restoration. Chemosphere $74,57-63$.

Dazy, M., Masfaraud, J.F., Férard J.F., 2009. Induction of oxidative stress biomarkers associated with heavy metal stress in Fontinalis antipyretica Hedw. Chemosphere 75, 297-302.

De Man, J.C., 1977. MPN tables for more than one test. European Journal of Applied Microbiology 4, 307-316.

Edwards, C.A., Fletcher, K.E., 1971. A comparison of extraction methods for terrestrial arthropods. In: Phillipson, J. (Ed.), Methods of Study in Quantitative Soil ecology: Population, Production and Energy Flow. Blackwell, Oxford, pp. 150185. 
Escarré, J., Lefèbvre Cl., Raboyau, S., Dossantos, A., Gruber, W., Cleyet Marel, J., Cl., Frérot, H., Noret, N., Mahieu., S., Collin, Ch., Van Oort F., 2011. Heavy metal concentration survey in soils and plants of the Les Malines mining district (Southern France): implications for soil restoration. Water, Air and Soil Pollution 216, 485-504.

Fjellberg, A., 1998. The Collembola of Fennoscandia and Denmark. I. Poduromorpha. Brill, Leiden.

Friesl, W., Friedl, J., Platzer, K., Horak, O., Gerzabek, M.H., 2006. Remediation of contaminated agricultural soils near a former $\mathrm{Pb} / \mathrm{Zn}$ smelter in Austria: Batch, pot and field experiments. Environmental Pollution 144, 40-50.

Gillet, S., Ponge, J.F., 2002. Humus forms and metal pollution in soil. European Journal of Soil Science 53, 529-539.

Gillet, S., Ponge, J.F., 2003. Changes in species assemblages and diets of Collembola along a gradient of metal pollution. Applied Soil Ecology 22, 127-138.

Gillet, S., Ponge, J.F., 2005. Species assemblages and diets of Collembola in the organic matter accumulated over an old tar deposit. European Journal of Soil Biology $41,39-44$.

Gisin, H., 1960. Collembolenfauna Europas. Muséum d'Histoire Naturelle, Geneva.

Hopkin, S.P., 1997. Biology of the Springtails. Oxford University Press, Oxford.

Hopkin, S.P., 2000. A key to the Collembola (springtails) of Britain and Ireland. Field Studies Council AIDGAP Guides 111, 1-245. 
ISO 8692, 1989. Water quality - Freshwater algal growth inhibition test with Scenedesmus subspicatus and Selenastrum capricornutum. International Organization for Standardization, Geneva.

Jordana, R., Arbea, J.I., Simón, C., Luciáñez, M.J., 1997. Fauna Iberica. VIII. Collembola Poduromorpha. CSIC, Madrid.

Knox, A.S., Seaman, J.C., Mench, M., J., Vangronsveld, J., 2001. Remediation of metal- and radionuclides-contaminated soils by in situ stabilization techniques, in: Iskandar, I.K. (Ed), Environmental Restoration of Metal-contaminated Soils. Lewis Publishers, Boca Raton, pp. 21-60.

Kumpiene, J., Lagerkvist, A., Maurice, C., 2008. Stabilization of As, $\mathrm{Cr}, \mathrm{Cu}, \mathrm{Pb}$ and $\mathrm{Zn}$ in soil using amendments - a review. Waste Management 28, 215-225.

Lambinon, J., Delvosalle, L., Duvignaud, J., 2004. Nouvelle Flore de la Belgique, du Grand-Duché de Luxembourg, du Nord de la France et des Régions Voisines (Ptéridophytes et Spermatophytes), 5th éd. Jardin Botanique de Belgique, Meise.

Laposi, R., Veres, S, Lakatos, G., Olah, V., Fieldsend, A., Meszaros, I., 2009. Responses of leaf traits of European beech (Fagus sylvatica L.) saplings to supplemental UV-B radiation and UV-B exclusion. Agricultural and Forest Meteorology 149, 745-755.

Lock, K., Janssen, C.R., 2003. Effect of new soil immobilizing agents on metal toxicity to terrestrial invertebrates. Environmental Pollution 121, 123-127.

Lock, K., Janssens, F., Janssen, C.R., 2003. Effects of metal contamination on the activity and diversity of springtails in an ancient $\mathrm{Pb}-\mathrm{Zn}$ mining area at Plombières, Belgium. European Journal of Soil Biology 39, 25-29. 
Lock, K., Janssen, C.R., 2005. Influence of soil zinc concentration on zinc sensitivity and functional diversity of microbial communities. Environmental Pollution 136, 275-281.

Lors, C., Tiffreau, C., Laboudigue, A., 2004. Effects of bacterial activities on the release of heavy metals from contaminated dredged sediments. Chemosphere 56, 619630.

Ma, Q.Y., Traina, S.J., Logan, T.J., 1993. In situ lead immobilization by apatite. Environmental Science and Technology 27, 1803-1810.

Madejon, E., Perez de Mora, A., Felipe, E., Burgos, P., Cabrera, F., 2006. Soil amendments reduce trace element solubility in a contaminated soil and allow regrowth of natural vegetation. Environmental Pollution 139, 40-52.

Mench, M., Vangronsveld, J., Didier, V., Clijsters, H., 1994a. Evaluation of metal mobility, plant availability and immobilization by chemical agents in a limedsilty soil. Environmental Pollution 86, 279-286.

Mench, M.J., Didier V.L., Löffler M., Gomez, A., Masson, P., 1994b. A mimicked insitu remediation study of metal-contaminated soils with emphasis on cadmium and lead. Journal of Environmental Quality 23, 58-63.

Mench, M.J., Manceau, A., Vangronsveld, J., Clijsters, H., Mocquot, B., 2000. Capacity of soil amendments in lowering the phytoavailability of sludge-borne zinc. Agronomie 20, 383-397.

Miretzky, P., Fernandez-Cirelli, A., 2007. Phosphates for Pb immobilization in soils: a review Environmental and Chemical Letters 6, 121-133. 
Misra, V., Chaturvedi, P. K., 2007. Plant uptake/bioavailability of heavy metals from the contaminated soil after treatment with humus soil and hydroxyapatite Environmental and Monitoring Assessment 133, 169-176.

Negim, O, Eloifi, B., Mench, M., Bes, C., Gaste, H., Motelica-Heino, M., Le Coustumer, P., 2010. Effect of basic slag addition on soil properties, growth and leaf mineral composition of beans in a Cu-contaminated soil. Journal of Soil and Sediment Contamination 19, 174-187.

NF EN 13657, 2003. Characterization of waste - Digestion for subsequent determination of aqua regia soluble portion of elements. AFNOR, Association française de normalisation, Paris.

NF ISO 10693, 1995. Soil quality - Determination of carbonate content - Volumetric method. AFNOR, Association Française de Normalisation, Paris.

NF ISO 11261, 1995. Soil quality - Determination of total nitrogen - Modified Kjeldahl method. AFNOR, Association Française de Normalisation, Paris.

NF X 31-107, 2003. Soil Quality - Particle size determination by sedimentation - Pipette method. AFNOR, Association Française de Normalisation, Paris.

NF X 31-130, 1999. Soil quality - Chemical methods - Determination of cathionic exchange capacity (CEC) and extractible cations. AFNOR, Association Française de Normalisation, Paris.

NF ISO 14235, 1998. Soil quality - Determination of organic carbon by sulfochromic oxidation. AFNOR, Association Française de Normalisation, Paris.

NF ISO 10390, 1994. Soil quality - Determination of pH. AFNOR, Association Française de Normalisation, Paris. 
Panfili, F.R., Manceau, A., Sarret, G., Spadini, L., Kirpichtchikova, T., Bert, V., Laboudigue, A., Marcus, M.A., Ahamdach, N., Libert, M.F., 2005. The effect of phytostabilization on $\mathrm{Zn}$ speciation in a dredged contaminated sediment using scanning electron microscopy, X-ray fluorescence, EXAFS spectroscopy, and principal components analysis. Geochimica et Cosmochimica Acta 69, 2265-2284.

Piélou, E.C. 1966. The measures of diversity in different types of biological collections. Journal of Theoretical Biology, 13, 131-144.

Piou, S.,Bataillard, P., Laboudigue, A., Férard, J.F., Masfaraud, J.F., 2009. Changes in the geochemistry and ecotoxicity of a $\mathrm{Zn}$ and $\mathrm{Cd}$ contaminated dredged sediment over time after land disposal. Environmental Research 109, 712-720.

Ponge, J.F., 2000. Vertical distribution of Collembola (Hexapoda) and their food resources in organic horizons of beech forests. Biology and Fertility of Soils, 32, $508-522$.

Potapov, M., 2001. Synopses on Palaearctic Collembola. III. Isotomidae. Abhandlungen und Berichte des Naturkundemuseums Görlitz 73, 1-603.

Prach, K., 2003. Spontaneaous succession in Central-European man-mad habitats: what information can be used in restoration practice? Applied Vegetation Science 6, 125-129.

Prevost, O., 2008. Destination des sédiments fluviaux contaminés retirés des canaux: optimisation des filières et possibilités de valorisation. Techniques Sciences Méthodes 9, 71-79. 
Ramsay, A.J., 1984. Extraction of bacteria from soil: efficiency of shaking or ultrasonification as indicated by direct counts and autoradiography. Soil Biology and Biochemistry 16, 475-481.

Rebele, F., Lehmann, C., 2001. Biological flora of Central Europe, Calamagrostis epigejos (L.) Roth. Flora, 196, 325-344.

Renella, G., Mench, M., Gelsomino, A., Landi, L., Nannipieri, P., 2005. Functional activity and microbial community structure in soils amended with bimetallic sludges. Soil Biology and Biochemistry 37, 1498-1506.

Robert, M., 1996. Soil: Interface in the Environment, Resource for the Development.. Masson, Paris (in French).

Ruttens, A., Mench, M., Colpaert, J., V., Boisson, J., Carleer, R., Vangronsveld, J., 2006. Phytostabilization of a metal contaminated sandy soil. I. Influence of compost and/or inorganic metal immobilizing soil amendments on phytotoxicity and plant availability of metals. Environmental Pollution 144, 524-532.

Ryan, R.P., Ryan, D.J., Dowling, D.N., 2005. Multiple metal resistant transferable phenotypes in bacteria as indicators of soil contamination with heavy metals. Journal of Soils and Sediments 5, 95-100.

Sandifer, R.D., Hopkin, S.P., 1997. Effects of temperature on the relative toxicities of $\mathrm{Cd}, \mathrm{Cu}, \mathrm{Pb}$, and $\mathrm{Zn}$ to Folsomia candida (Collembola). Ecotoxicology and Environmental Safety, 37, 125-130.

Shannon, C.E., Weaver, W., 1949. The Mathematical Theory of Communication. University of Illinois Press, Urbana. 
Skousen, J.G., Johnson, C.D., Garbutt, K., 1994. Natural revegetation of 15 abandoned mine land sites in West Virginia. Journal of Environmental Quality 23, 12241230.

Sobolev, D.,. Begonia, M., F., T., 2008. Effects of heavy metal contamination upon soil microbes: Lead-induced changes in general and denitrifying microbial communities as evidenced by molecular markers. International Journal of Environmental Research and Public Health 5, 450-456.

Sørensen, T., 1948. A method of establishing groups of equal amplitude in plant sociology based on similarity of species and its application to analyses of the vegetation on Danish commons. Biologiske Skrifter 5, 1-34.

Strojan, C.L., 1978. The impact of zinc smelter emissions on forest litter arthropods. Oikos 31, 41-46.

Tyler, G., Balsberg Pahlsson, M., Bengtsson, G., Baath, E., Tranvik, L., 1989. Heavymetal ecology of terrestrial plants, microorganisms and invertebrates - a review. Water, Air and Soil Pollution 47, 189-215.

Taylor, J.P., Wilson, B., Mills, M.S., Burns, R.G., 2002. Comparison of microbial numbers and enzymatic activities in surface soils and subsoils using various techniques. Soil Biology and Biochemistry 34, 387-401.

Vangronsveld, J., Van Assche, F., Clijsters, H., 1995. Reclamation of a bare industrial area contaminated by non-ferrous metals: in situ metal immobilization and revegetation. Environmental Pollution 87, 51-59.

Vangronsveld, J., Colpaert, J., Van Tichelen, K., 1996. Reclamation of a bare industrial area contaminated by non-ferrous metals: physico-chemical and biological 

Pollution 94, 131-140.

881 Vassilev, A., Schwitzguébel, J., P., Thewys, T., van der Lelie, D., Vangronsveld, J., 2004. The use of plants for remediation of metal-contaminated soils. ScientificWorld Journal 4, 9-34.

884

Zimdars, B., Dunger, W., 1994. Synopses on Palaearctic Collembola. I. Tullbergiinae. Abhandlungen und Berichte des Naturkundemuseums Görlitz 68, 1-71.

886 
888 Figure 1.

$889 \mathrm{Fv} / \mathrm{Fm}$ ratios and antioxidant enzyme activities ( $\mu$ moles/min/mg proteins excepted for

890 SOD expressed as U/mg proteins) in C. epigejos leaves collected from control area

891 (CA), untreated plot (NT), plots treated with hydroxylapatite (HA) or Thomas basic slag

892 (TBS). Different letters indicate significant differences between plots according to post-

893 hoc Tukey HSD tests run when ANOVA was significant.

894 Figure 2.

$895 \mathrm{Fv} / \mathrm{Fm}$ ratios and antioxidant enzyme activities ( $\mu$ moles/min/mg proteins excepted for

896 SOD expressed as U/mg proteins) in $U$. dioica leaves collected from control area (CA),

897 untreated plot (NT), plots treated with hydroxylapatite (HA) or Thomas basic slag

898 (TBS). Different letters indicate significant differences between plots according to post-

899 hoc Tukey HSD tests run when ANOVA was significant.

900 Figure 3.

901 Distribution of gut contents among the 403 collembolan specimens collected in three

902 treatments and in the control area (CA). Letters indicate significant differences among 903 means at 0.05 level (ANOVA followed by SNK procedure). 
906 Main characteristics and (pseudo)-total metal concentrations of sediments (NT,

907 untreated; HA, hydroxylapatite; TBS, Thomas Basic Slag) and the control area (CA).

908 For trace elements (except for $\mathrm{CA}$ ) and $\mathrm{pH}$, values are means of triplicate measurements

909 and their standard deviation.

\begin{tabular}{|c|c|c|c|c|}
\hline & CA & NT & HA & TBS \\
\hline \multicolumn{5}{|l|}{$\begin{array}{l}\text { Particle size } \\
\text { distribution }(\%)\end{array}$} \\
\hline Sand & 13.2 & 69.6 & 60.1 & 65.4 \\
\hline Silt & 70.3 & 14 & 21.1 & 19.1 \\
\hline Clay & 16.5 & 16.4 & 18.8 & 15.5 \\
\hline Organic C (\%) & 1.64 & 3.2 & 4.1 & 3.7 \\
\hline$N\left(\right.$ g kg $\left.^{-1}\right)$ & 1.6 & 1.62 & 1.67 & 2.04 \\
\hline $\mathrm{CaCO}_{3}\left(\mathrm{~g} \mathrm{~kg}^{-1}\right)$ & 63 & 76 & 76 & 105 \\
\hline $\mathrm{CEC}\left(\mathrm{cmol} \mathrm{kg}^{-1}\right)$ & 13.3 & 7.2 & 8.3 & 11.3 \\
\hline pH $\mathbf{H a t e r}_{\text {}}$ & $7.6 \pm 0.1$ & $7.0 \pm 0,1$ & $7.3 \pm 0,1$ & $7.7 \pm 0,3$ \\
\hline $\mathrm{Zn}\left(\mathrm{mg} \mathrm{kg}^{-1} \mathrm{DW}\right)$ & 75 & $3250 \pm 319$ & $2521 \pm 461$ & $3029 \pm 217$ \\
\hline $\mathrm{Cd}\left(\mathrm{mg} \mathrm{kg}^{-1} \mathrm{DW}\right)$ & 0.4 & $84 \pm 2$ & $67 \pm 11$ & $86 \pm 8$ \\
\hline Pb (mg kg $\left.{ }^{-1} \mathrm{DW}\right)$ & 27 & $448 \pm 82$ & $389 \pm 96$ & $413 \pm 57$ \\
\hline $\mathrm{Cu}\left(\mathrm{mg} \mathrm{kg}^{-1} \mathrm{DW}\right)$ & 17 & $93 \pm 13$ & $94 \pm 11$ & $123 \pm 29$ \\
\hline As (mg kg $\left.{ }^{-1} \mathrm{DW}\right)$ & 8 & $53 \pm 4$ & $48 \pm 4$ & $45 \pm 2$ \\
\hline
\end{tabular}

910 
912 Concentrations of trace elements extracted from soils by $0.01 \mathrm{M} \mathrm{Ca}\left(\mathrm{NO}_{3}\right)_{2}$ (means of

913 triplicate values \pm standard deviation) and corresponding leachate ecotoxicity.

914 Significant differences among means at 0.05 level were indicated by different letters. $\mathrm{nr}$

$915=$ not reached

\begin{tabular}{|c|c|c|c|}
\hline & NT & HA & TBS \\
\hline $\mathrm{Zn}\left(\mathrm{mg} \mathrm{kg}^{-1} \mathrm{DW}\right)$ & $12.05 \mathrm{a} \pm 0.96$ & $7.77 \mathrm{ab} \pm 0.33$ & $2.07 b \pm 2.73$ \\
\hline Cd & $0.64 a \pm 0.12$ & $0.41 \mathrm{ab} \pm 0.04$ & $0.12 b \pm 0.13$ \\
\hline $\mathbf{P b}$ & $<0.07$ & $<0.07$ & $<0.07$ \\
\hline $\mathbf{C u}$ & $0.12 \mathrm{a} \pm 0.01$ & $0.13 a \pm 0.02$ & $0.21 \mathrm{a} \pm 0.14$ \\
\hline As & $<0.1$ & $<0.1$ & $<0.1$ \\
\hline Microtox $\mathrm{EC}_{50}(\%)$ & $\mathrm{nr}$ & $\mathrm{nr}$ & $\mathrm{nr}$ \\
\hline $\begin{array}{l}\text { Microtox } \\
(\% \text { luminescent } \\
\text { inhibition at } 90 \%)\end{array}$ & 44 & 20.5 & 6.3 \\
\hline Algae test $\mathrm{IC}_{50}(\%)$ & 12.8 & 19.2 & $\mathrm{nr}$ \\
\hline $\begin{array}{l}\text { Algal test } \\
(\% \text { inhibition at } 90 \%)\end{array}$ & 100 & 100 & 36.4 \\
\hline
\end{tabular}

916

917 
919 Composition of the plant community in the three treatment plots. Species richness is the number of species. $\mathrm{H}^{\prime}$ is the Shannon-Weaver index. $\mathrm{J}$ is the Piélou equitability index.

\begin{tabular}{|c|c|c|c|c|c|c|}
\hline Family & Species & Plant type & $\begin{array}{l}\text { Plant life } \\
\text { cycle }\end{array}$ & NT & $\mathbf{H A}$ & TBS \\
\hline Apiaceae & Pastinaca sativa & Herbaceous & Annual & 0.47 & 0.46 & 0 \\
\hline \multirow[t]{3}{*}{ Asteraceae } & Eupatorium cannabinum & Herbaceous & Perennial & 0 & 3.15 & 0.29 \\
\hline & Achillea millefolium & Herbaceous & Annual & 0.12 & 7.59 & 0 \\
\hline & Cirsium arvense & Herbaceous & Perennial & 0.47 & 0 & 1.39 \\
\hline Brassicaceae & Cardamine hirsuta & Herbaceous & Annual & 6.18 & 1,76 & 0.19 \\
\hline Boraginaceae & Myosotis arvense & Herbaceous & Annual & 0.12 & 0.09 & 0 \\
\hline Convolvulaceae & Convolvulus arvensis & Herbaceous & Perennial & 0 & 0.46 & 0 \\
\hline \multirow[t]{2}{*}{ Cyperaceae } & Carex hirta & Herbaceous & Perennial & 11.55 & 1.85 & 0.33 \\
\hline & Carex cuprina & Herbaceous & Perennial & 0.12 & 0.09 & 0 \\
\hline \multirow[t]{2}{*}{ Lamiaceae } & Glechoma hederacea & Herbaceous & Perennial & 11.67 & 22.85 & 7.08 \\
\hline & Lycopus europaeus & Herbaceous & Perennial & 0.70 & 1.57 & 0 \\
\hline Onagraceae & Epilobium angustifolium & Herbaceous & Annual & 0.35 & 1.2 & 11.76 \\
\hline \multirow[t]{3}{*}{ Poaceae } & Deschampsia cespitosa & Herbaceous & Perennial & 1.52 & 1.76 & 0 \\
\hline & Festuca rubra & Herbaceous & Perennial & 3.73 & 6.85 & 0 \\
\hline & Phalaris arundinacea & Herbaceous & Perennial & 0 & 0.93 & 33.09 \\
\hline
\end{tabular}




\begin{tabular}{|c|c|c|c|c|c|c|}
\hline & Calamagrostis epigejos & Herbaceous & Perennial & 46.91 & 19.98 & 30.00 \\
\hline & Holcus lanatus & Herbaceous & Perennial & 0 & 2.22 & 0.1 \\
\hline & Poa trivialis & Herbaceous & Perennial & 0 & 0 & 0.14 \\
\hline Ranunculaceae & Ranunculus repens & Herbaceous & Perennial & 0.12 & 1.11 & 0 \\
\hline Rubiaceae & Galium aparine & Herbaceous & Annual & 2.22 & 2.13 & 16.40 \\
\hline Scrophulariaceae & Linaria vulgaris & Herbaceous & Perennial & 0 & 1.67 & 0 \\
\hline Urticaceae & Urtica dioica & Herbaceous & Perennial & 2.33 & 4.63 & 0.86 \\
\hline \multirow[t]{2}{*}{ Betulaceae } & Betula pendula & Tree & Perennial & 8.05 & 12.67 & 0.05 \\
\hline & Betula pubescens & Tree & Perennial & 1.87 & 2.31 & 0.05 \\
\hline Fagaceae & Quercus robur & Tree & Perennial & 0.12 & 0.28 & 0 \\
\hline \multirow[t]{3}{*}{ Salicaceae } & Salix sp. & Tree & Perennial & 0 & 0.46 & 0 \\
\hline & Salix alba & Tree & Perennial & 0.12 & 1.02 & 0 \\
\hline & Salix capraea & Tree & Perennial & 1.40 & 0.93 & 0 \\
\hline \multirow{3}{*}{$\begin{array}{l}\text { Species richness } \\
\text { H' } \\
\text { J } \\
\end{array}$} & & & & 21 & 26 & 14 \\
\hline & & & & 2.7 & 3.6 & 2.35 \\
\hline & & & & 0.62 & 0.77 & 0.62 \\
\hline
\end{tabular}

921 For species, values were percent numbers of individuals per species and per unit 922 surface. 
925 Concentrations (mg/kg DW) in shoots of Calamagrostis epigejos and Urtica dioica.

\begin{tabular}{|c|c|c|c|c|}
\hline & $\mathbf{C A}$ & NT & HA & TBS \\
\hline \multicolumn{5}{|c|}{ Calamagrostis epigejos } \\
\hline Cd & $<0.05$ & $2.16(\mathrm{a}) \pm 1.4$ & $2.51(\mathrm{a}) \pm 1.1$ & 0.34 (b) \pm 0.18 \\
\hline Zn & 23 (a) \pm 9 & 121 (c) \pm 58 & $98(\mathrm{bc}) \pm 32.6$ & $44(a b) \pm 20$ \\
\hline $\mathbf{P b}$ & $<1$ & $<1$ & $<1$ & $<1$ \\
\hline $\mathbf{C u}$ & $4.5(a b) \pm 0,9$ & $3.5(\mathrm{a}) \pm 0.3$ & $5.1(b) \pm 0.7$ & $4.3(\mathrm{ab}) \pm 0.2$ \\
\hline As & $<0.5$ & $<0.5$ & $<0.5$ & $<0.5$ \\
\hline $\mathbf{C a}$ & $405 \pm 331$ & $617 \pm 115$ & $769 \pm 273$ & $791 \pm 243$ \\
\hline $\mathbf{F e}$ & $23 \pm 2$ & $52 \pm 56$ & $33 \pm 5$ & $23 \pm 1$ \\
\hline Mg & $453(b) \pm 121$ & 251 (a) \pm 83 & $532(b) \pm 147$ & $446(a b) \pm 62$ \\
\hline Mn & $16(a) \pm 5$ & 51 (b) \pm 8 & 13 (a) \pm 3 & $15(\mathrm{a}) \pm 1$ \\
\hline $\mathbf{P}$ & $1570 \pm 247$ & $1530 \pm 189$ & $1863 \pm 875$ & $1175 \pm 235$ \\
\hline $\mathbf{N a}$ & $123(a b) \pm 4$ & 115 (a) \pm 4 & $131(b) \pm 12$ & $119(a b) \pm 13$ \\
\hline $\mathbf{K}$ & 12407 (a) \pm 1329 & $14523(\mathrm{ab}) \pm 1543$ & 16648 (b) \pm 2620 & $13074(\mathrm{a}) \pm 1288$ \\
\hline Al & n.d & 5 (a) \pm 2 & $8.5(b) \pm 1.6$ & $24(\mathrm{c}) \pm 1$ \\
\hline \multicolumn{5}{|c|}{ Urtica dioica } \\
\hline $\mathbf{C d}$ & 0.06 (a) \pm 0.01 & $1.5(b) \pm 1.3$ & $0.9(\mathrm{ab}) \pm 0.3$ & $0.36(a b) \pm 0.18$ \\
\hline $\mathbf{Z n}$ & 12 (a) \pm 1 & $210(b) \pm 104$ & $184(b) \pm 28$ & $145(b) \pm 21$ \\
\hline $\mathbf{P b}$ & $<1$ & $<1$ & $<1$ & $<1$ \\
\hline $\mathbf{C u}$ & 4.0 (a) \pm 0.5 & $6.9(b) \pm 1.9$ & $6.8(b) \pm 1.9$ & $7.4(b) \pm 0.9$ \\
\hline As & $<0.5$ & $<0.5$ & $<0.5$ & $<0.5$ \\
\hline $\mathbf{C a}$ & $19719 \pm 8227$ & $20945 \pm 3292$ & $24398 \pm 2407$ & $23901 \pm 3334$ \\
\hline $\mathbf{F e}$ & 35 (a) \pm 6 & $51(a b) \pm 10$ & $60(b) \pm 12$ & $43(a b) \pm 11$ \\
\hline $\mathrm{Mg}$ & $1726 \pm 1753$ & $1278 \pm 433$ & $2176 \pm 285$ & $1722 \pm 241$ \\
\hline Mn & $13 \pm 3$ & $12 \pm 6$ & $11 \pm 2$ & $12 \pm 2$ \\
\hline $\mathbf{P}$ & 2314 (a) \pm 267 & 4229 (b) \pm 465 & 4310 (b) \pm 841 & 6096 (c) \pm 563 \\
\hline $\mathbf{N a}$ & $136 \pm 38$ & $177 \pm 41$ & $162 \pm 20$ & $149 \pm 12$ \\
\hline $\mathbf{K}$ & 17355 (a) \pm 4593 & $19029(a b) \pm 1434$ & $\begin{array}{c}23699(\mathrm{bc}) \pm \\
1721\end{array}$ & 27963 (c) \pm 2117 \\
\hline Al & n.d & $20 \pm 8$ & $32 \pm 10$ & $28 \pm 12$ \\
\hline
\end{tabular}

926 Mean values and standard deviations $\left(\mathrm{n}=5 ; \mathrm{mg} \mathrm{kg}^{-1} \mathrm{DW}\right)$. Different letters indicate

927 significant differences among plots for $\alpha=0.05$. 
929 Table 5. Correlation analysis between shoot element concentrations and antioxidant 930 enzyme activities in leaves $(n=20)$.

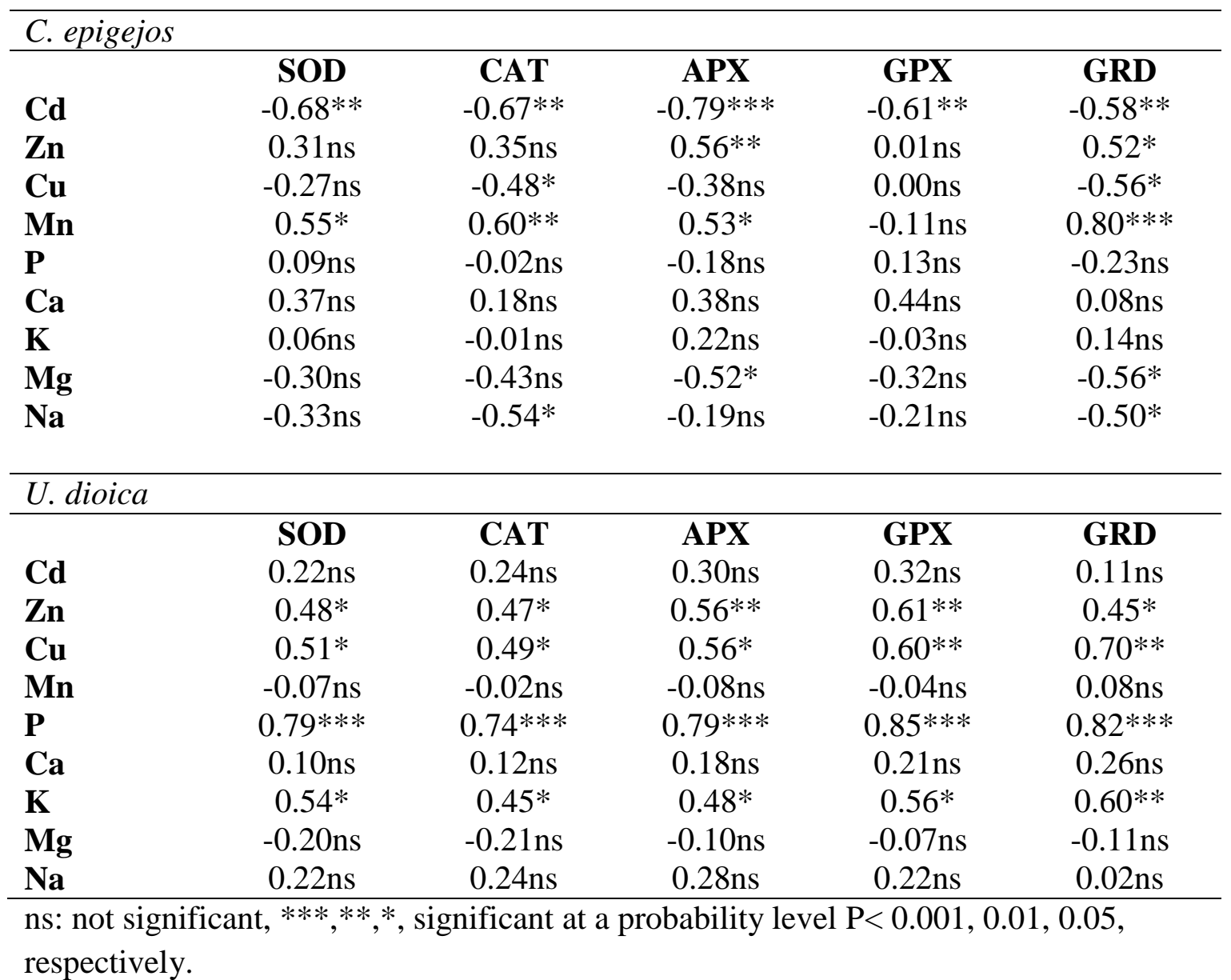

933

934

935

936

937

938

939

940

941 
Table 6. Species distribution and biodiversity indices of collembolan species.

ANOVA: NS $=$ not significant $; * * \mathrm{P}<0.01$. Post-hoc tests $(\mathrm{SNK}$ procedure): significant differences indicated by different letters

\begin{tabular}{lccccc}
\hline & CA & NT & HA & TBS & F value \\
\hline Dicyrtomina minuta & 0 & 0 & 0 & $0.33 \pm 0.27$ & $1 \mathrm{NS}$ \\
Entomobrya sp. & 0 & $1.33 \pm 1.09$ & 0 & 0 & $1 \mathrm{NS}$ \\
Folsomia candida & $0.33 \pm 0.27$ & $0.33 \pm 0.27$ & 0 & $1 \pm 0.82$ & $0.58 \mathrm{NS}$ \\
Friesea truncata & $0^{\mathrm{b}}$ & $0^{\mathrm{b}}$ & $0^{\mathrm{b}}$ & $4 \pm 1.25^{\mathrm{a}}$ & $6.86^{* *}$ \\
Hererosminthurus claviger & $0.33 \pm 0.27$ & 0 & 0 & 0 & $1 \mathrm{NS}$ \\
Isotomodes productus & $0.67 \pm 0.54$ & 0 & 0 & $2.67 \pm 1.78$ & $1.22 \mathrm{NS}$ \\
Lepidocyrtus lignorum & 0 & 0 & 0 & $0.33 \pm 0.27$ & $1 \mathrm{NS}$ \\
Mesaphorura florae & $1.33 \pm 0.72$ & $6.33 \pm 2.13$ & $21.67 \pm 7.92$ & $25.33 \pm 8.57$ & $2.56 \mathrm{NS}$ \\
Mesaphorura macrochaeta & $3.33 \pm 2.72$ & 0 & $0.67 \pm 0.27$ & $0.67 \pm 0.54$ & $0.75 \mathrm{NS}$ \\
Mesaphorura pongei & 0 & 0 & 0 & $1.33 \pm 1.09$ & $1 \mathrm{NS}$ \\
Orchesella sp. & 0 & $0.33 \pm 0.27$ & $0.33 \pm 0.27$ & 0 & $0.67 \mathrm{NS}$ \\
Parisotoma notabilis & $6.67 \pm 1.96$ & $4.67 \pm 1.66$ & $5.67 \pm 2.13$ & $0.33 \pm 0.27$ & $1.85 \mathrm{NS}$ \\
Proisotoma minima & $7 \pm 2.45$ & $9 \pm 2.94$ & $0.67 \pm 0.54$ & $7 \pm 2.36$ & $1.71 \mathrm{NS}$ \\
Tomocerus vulgaris & 0 & 0 & $0.33 \pm 0.27$ & 0 & $1 \mathrm{NS}$ \\
Total abundance & $19.67 \pm 3.07$ & $22 \pm 5.44$ & $29.33 \pm 6.4$ & $43 \pm 10.6$ & $1.53 \mathrm{NS}$ \\
Species richness & $4 \pm 0.47$ & 4 & $3.67 \pm 0.27$ & $5.67 \pm 1.19$ & $1.28 \mathrm{NS}$ \\
Shannon Index & $1.44 \pm 0.21$ & $1.65 \pm 0.07$ & $1.09 \pm 0.32$ & $1.78 \pm 0.26$ & $1.09 \mathrm{NS}$ \\
Equitability Index & $0.72 \pm 0.04$ & $0.82 \pm 0.04$ & $0.56 \pm 0.15$ & $0.75 \pm 0.03$ & $1.25 \mathrm{NS}$ \\
\hline
\end{tabular}


946 Table 7. Total and specific bacterial numbers

947 Counts of total bacteria, acidophilic sulphur-oxidising bacteria (ASOB), neutrophilic 948 sulphur-oxidising bacteria (NSOB) and sulphate-reducing bacteria (SRB) (expressed as 949 bacteria $\mathrm{g}^{-1}$ dry soil) collected from untreated plot (NT), plot treated with 950 hydroxylapatite (HA) or Thomas basic slag (TBS). Values are expressed as means \pm 951 standard deviation in triplicate samples. Values with the same letters are not 952 significantly different according to ANOVA used Newman-Keuls (SNK) test at $\mathrm{P} \leq$ 9530.05.

\begin{tabular}{cccc}
\hline & NT & HA & TBS \\
& & & \\
\hline Total bacteria & $2.1210^{7}$ & $5.5810^{7}$ & $1.7510^{8}$ \\
& $\pm 5.0910^{5} \mathrm{c}$ & $\pm 7.9010^{6} \mathrm{~b}$ & $\pm 1.8610^{6} \mathrm{a}$ \\
ASOB & $3.6910^{3}$ & $7.3610^{3}$ & $2.9310^{3}$ \\
& $\pm 2.3110^{1} \mathrm{a}$ & $\pm 3.1910^{3} \mathrm{a}$ & $\pm 1.2910^{3} \mathrm{a}$ \\
NSOB & $1.0010^{5}$ & $3.0510^{5}$ & $1.4510^{5}$ \\
& $\pm 6.7810^{4} \mathrm{a}$ & $\pm 1.1510^{5} \mathrm{a}$ & $\pm 4.6210^{4} \mathrm{a}$ \\
SRB & $6.9710^{1}$ & $5.9710^{1}$ & $5.9710^{1}$ \\
& $\pm 4.0410^{1} \mathrm{a}$ & $\pm 2.8910^{1} \mathrm{a}$ & $\pm 2.8910^{1} \mathrm{a}$ \\
\hline
\end{tabular}

954 
957 Treatments $(\mathrm{NT}=$ Untreated, $\mathrm{HA}=$ Hydroxyapatite, $\mathrm{TBS}=$ Thomas Basic Slag $)$ ranked according to 24 variables describing optimal features of plant, faunal and microbial communities and sediment toxicity. Average ranks are indicated by mean \pm standard

960 deviation.

\section{Variable}

NT

HA

TBS

Plant, faunal and microbial communities good health

\begin{tabular}{lccc}
\hline Vegetation succession state & 2 & 1 & 3 \\
Plant species richness & 2 & 1 & 3 \\
Plant species diversity & 2 & 1 & 3 \\
Plant species equitability & 2.5 & 1 & 2.5 \\
Fv/Fm in $U$. dioica & 2 & 1 & 3 \\
Collembola abundance & 3 & 2 & 1 \\
Collembola species richness & 2 & 3 & 1 \\
Collembola species diversity & 2 & 3 & 1 \\
Collembola species equitability & 1 & 3 & 2 \\
Total bacteria abundance & 3 & 2 & 1 \\
\hline Sediment toxicity & & & \\
\hline Cd mobility & 3 & 2 & 1 \\
Zn mobility & 3 & 2 & 1 \\
Microtox & 3 & 2 & 1 \\
Algal test & 2.5 & 2.5 & 1 \\
Cd in C. epigejos & 2 & 3 & 1 \\
Zn in C. epigejos & 3 & 2 & 1 \\
Cd in Urtica & 3 & 2 & 1 \\
Zn in Urtica & 3 & 2 & 1 \\
\hline SOD in C. epigejos & 3 & 1 & 2 \\
CAT in C. epigejos & 3 & 1 & 2 \\
APX in C. epigejos & 3 & 1 & 2 \\
CAT in $U$. dioica & 2 & 1 & 3 \\
APX in U. dioica & 2 & 1 & 3 \\
\hline Average rank & 2 & 1 & 3 \\
\hline
\end{tabular}

961 

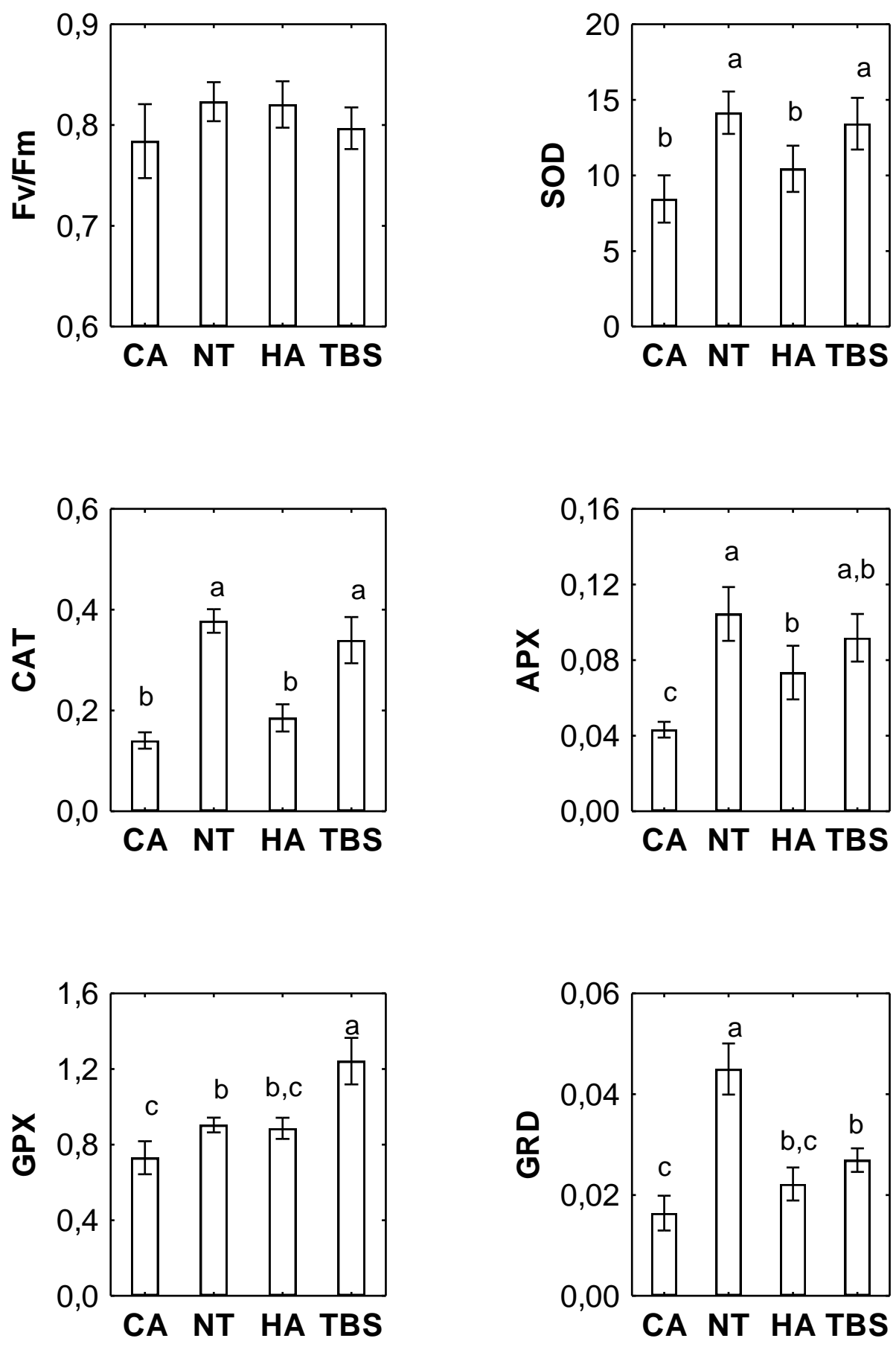

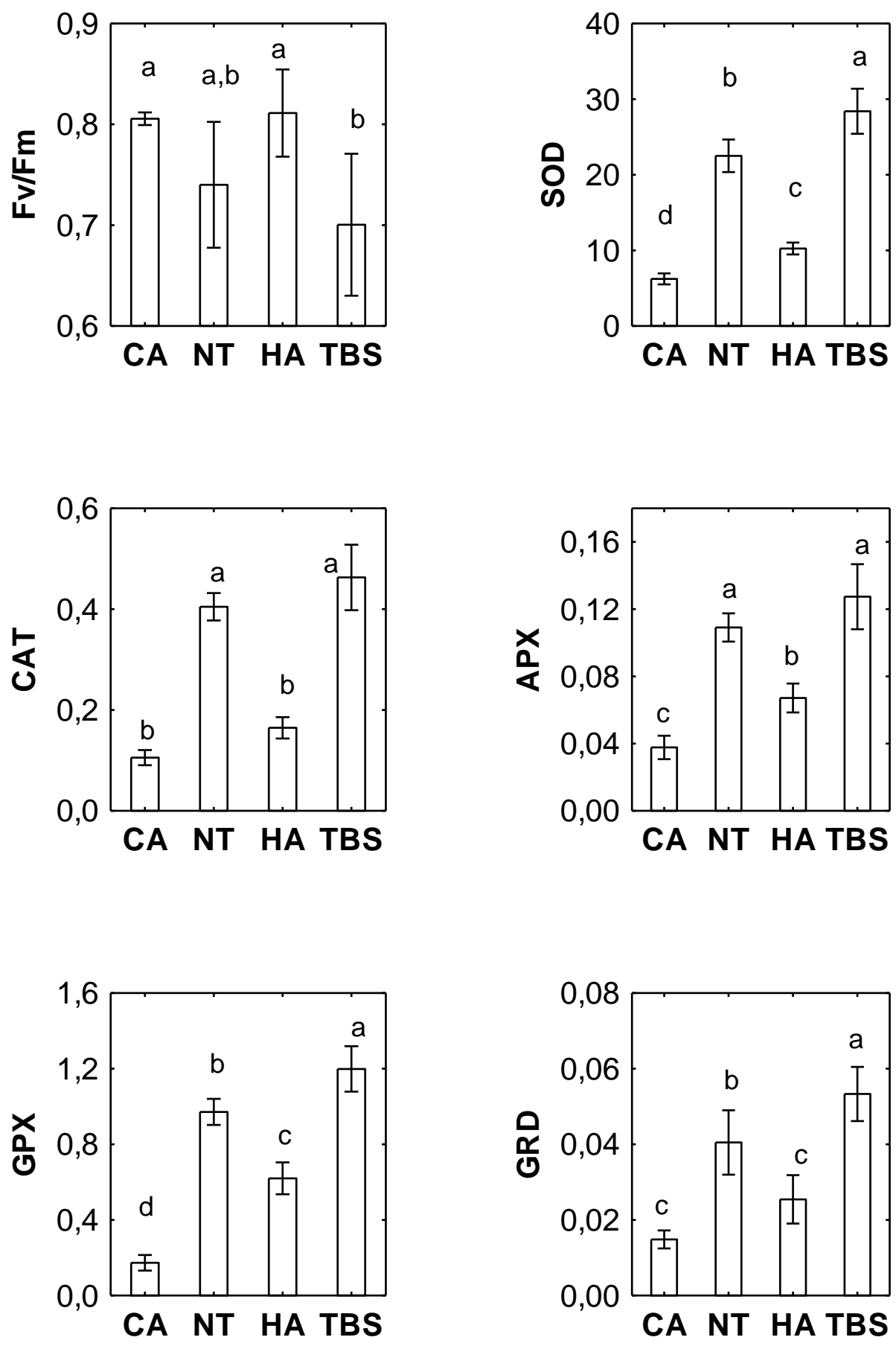
FIGURE 3

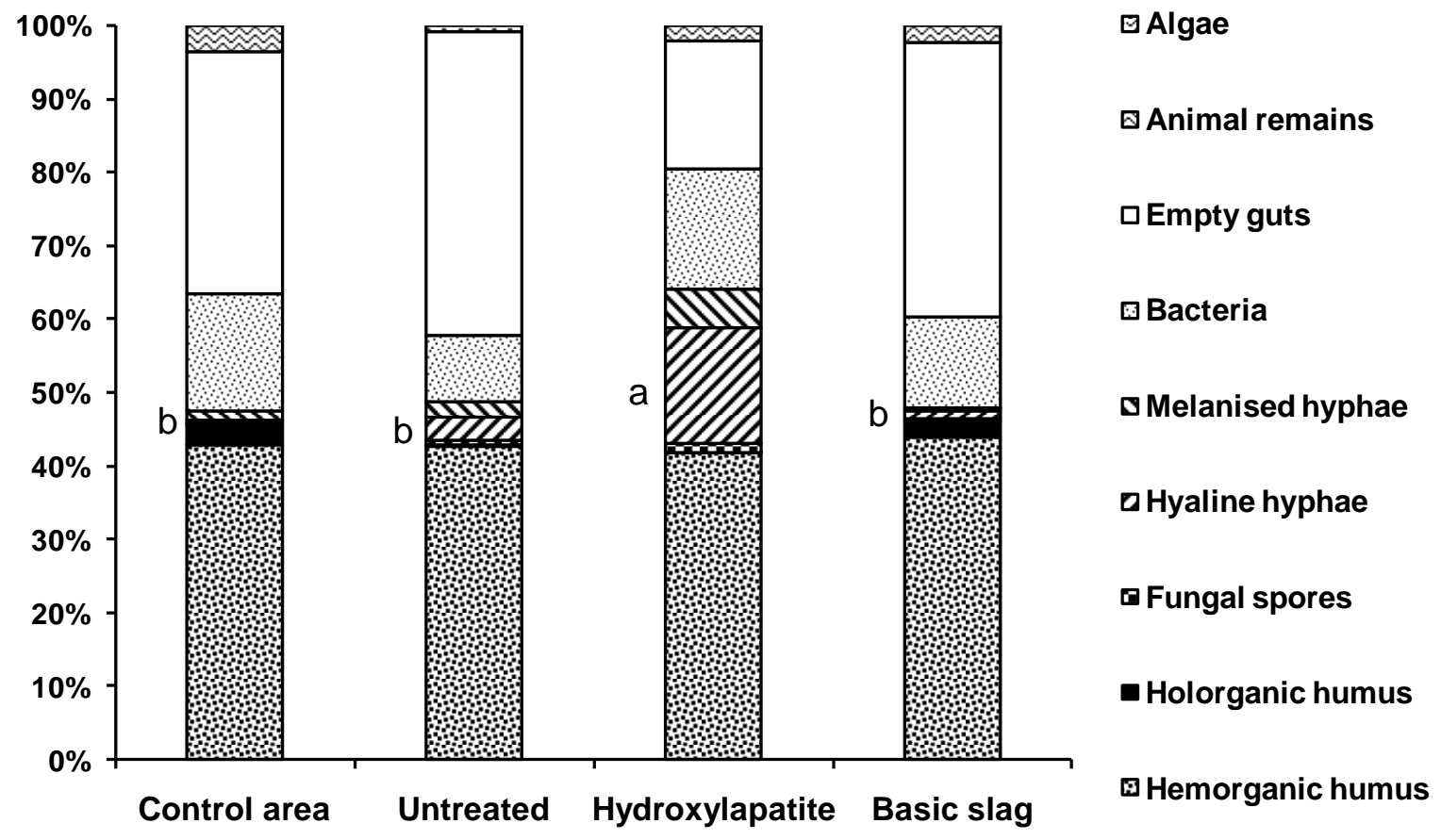

